\title{
Tras bastidores del Reglamento a la Ley de Arbitraje y Mediación
}

\author{
Hugo García Larriva* \\ Bernarda Muriel Bedoya** \\ Recibido/Received: 11/10/2021 \\ Aceptado/Accepted:13/10/2021
}

\begin{abstract}
SUMARIO: 1. Introducción. 2. La naturaleza negocial del arbitraje y la suplencia de la normativa procesal ordinaria. 3. El arbitraje con el sector público. 3.1. Suscripción de convenios arbitrales con el sector público. 3.2. Arbitrabilidad en disputas con el sector público. 3.3. La autorización del Procurador General del Estado. 4. La acción de nulidad de laudos arbitrales. 4.1. Principios aplicables al procedimiento de nulidad. 4.2. Tramitación de la acción de nulidad por las Cortes Provinciales. 5. La ejecución de laudos arbitrales internacionales. 6. Regulación de la justicia cautelar. 6.1. Reco-nocimiento de la figura del árbitro de emergencia. 6.2. Medidas preventivas y la justicia ordinaria. 7. Temas misceláneos. 7.1. La confidencialidad del arbitraje y su alcance. 7.2. La responsabilidad de los árbitros. 7.3. Competencia de los árbitros y el plazo para dictar el laudo. 7.4. Regulación del arbitraje internacional. 7.5. Extensión del convenio arbitral.
\end{abstract}

Resumen: El presente trabajo estudia el recién expedido Reglamento a la Ley de Arbitraje y Mediación. Se analiza cada tema a través de una recapitulación de las disposiciones vigentes en nuestro ordenamiento y la jurisprudencia relevante. Concluimos que las normas del Reglamento constituyen, por un lado, una recopilación

\footnotetext{
* Socio de Carmigniani Pérez Abogados. Profesor Universidad San Francisco de Quito (USFQ). Abogado por la Universidad San Francisco de Quito. Especialista Superior en Derecho Procesal por la Universidad Andina Simón Bolívar - Sede Ecuador. Magíster en Derecho de Empresa por la USFQ. LL.M. en Derecho Internacional por la Universidad de Cambridge. Correo electrónico: hgarcia@cplaw.ec

** Asociada de Carmigniani Pérez Abogados. Abogada por la Universidad San Francisco de Quito. Correo electrónico: bmuriel@cplaw.ec
} 
de las mejores prácticas en arbitraje que ya se habían consagrado en muchas decisiones de cortes y tribunales arbitrales, y, por otro lado, un desarrollo progresivo de las normas legales en materia arbitral.

Palabras Clave: Reglamento a la Ley de Arbitraje y Mediación, modernización, autonomía de la voluntad, justicia arbitral.

\section{Behind the scenes of the Regulations to the Arbitration and Mediation Law}

Aвstract: This paper studies the recently issued Regulations to the Arbitration and Mediation Law ("Reglamento a la Ley de Arbitraje y Mediación"). Each topic is analyzed through a recapitulation of the provisions in force in our legal system and the relevant jurisprudence on the subject. Concluding that the Regulations, on one hand, is a compilation of the best practices in arbitration that have already been enshrined in many court decisions and arbitrations tribunals; and on the other hand, a progressive development of the legal norms in arbitration matters.

Keywords: Regulations to the Arbitration and Mediation Law, modernization, party autonomy, arbitral justice.

\section{INTRODUCCIÓN}

El año de 1799 fue un año, digamos, peculiar. En enero, el gobierno de su majestad Jorge II del Reino Unido impuso, por primera vez, un impuesto a la renta. En marzo, los rusos y turcos toman de los franceses la estratégica isla de Corfú. En julio se descubre la Piedra de Rosetta que permitirá, muchos años luego, descifrar los jeroglíficos egipcios. En noviembre, Napoleón derriba el Directorio, establece el Consulado y se convierte en Primer Cónsul. En 1799 sucedió, además, un hecho curioso. En una fría y lluviosa mañana londinense llegó al despacho del doctor George Shaw en el Museo Británico una caja. Adentro de ella había un nuevo espécimen que venía desde Australia. Al abrirlo el doctor Shaw vio algo que le parecía típico de la época: una farsa creada por aventureros mercaderes. No era raro que a su despacho lleguen supuestas sirenas, que no eran nada más que la unión de una cola 
de pescado al torso de algún primate de menor tamaño. Por eso, con decisión, no dudó en usar el escarpelo para descartar alguna charlatanería. Pero, joh sorpresa! Este caso era distinto. Su reseña decía: pico de pato; patas palmadas; aguijón en las patas; cuerpo y cola de castor; pone huevos, pero tiene mamas. Al presentarlo en la comunidad académica británica hubo varias reacciones. Algunos lo llamaron embustero y farsante. Otros, que él atentaba contra la ciencia. Aquellos más audaces decían que se trataba de una especie antigua de patos. Sus contrarios, que era un castor con pico. El doctor Shaw muy probablemente llamó a la cordura. “iNada de eso!", seguramente gritó. No era embuste alguno. Se trataba de un nuevo espécimen, un marsupial que lo bautizó "Platypus anatinus": el ornitorrinco.

Lo relatado no llama la atención. Imagínense la Inglaterra de esa época. Ver un animal que a nuestros ojos es desconocido, pero se parece a algo que sí conocemos, sea un pato o un castor. Seguro y también agarrábamos el escarpelo para encontrar el hilo o la goma que unían el pico al cuerpo del roedor. Y eso no sería sino normal. Es una tendencia natural del ser humano el describir la realidad a la que se aboca a partir de su conocimiento previo. Es inherente a nuestra condición y no lo podemos evitar. Aplicamos a nuevas fenomenologías las categorías pertenecientes a nuestro conocimiento acumulado. Pero es asimismo natural al proceso de conocimiento el que creemos nuevas categorías cuando un fenómeno escapa, en todo o parte, a las preexistentes. El arbitraje no es ajeno a lo anterior.

El arbitraje en el Ecuador es fundamentalmente una institución nueva ${ }^{1}$. Luego, no es raro que el primer acercamiento que se realizó al arbitraje fue desde la práctica y con los ojos del litigio en cortes ordinarias. El lenguaje usado por directores de centros y árbitros suelen estar empapados del argot judicial. Las formas, ritos y protocolos de la normativa procesal ordinaria fueron, en la práctica, traspasados al arbitraje. Y es que al presentar el arbitraje a la comunidad legal ecuatoriana, esta la vio como un juicio ordinario frente a personas privadas. Nada más. Esto, además, provocó cierto recelo en la esfera de lo público que miró al arbitraje como producto

1. Si bien ha estado reconocido desde principios de la República, su verdadera expansión y práctica intensa comienza con la expedición de la Ley de Arbitraje y Mediación en 1997. 
de un inexistente conflicto con lo privado. Con la expansión del arbitraje en Ecuador, su estudio profundo y el contacto con prácticas internacionales, hemos interiorizado que el arbitraje no es un juicio ordinario ni una artimaña creada por aventureros mercaderes -como algunos políticos-, en su momento, lo quisieron pintar. Es sin lugar a dudas, una nueva especie: un ornitorrinco.

En este devenir del arbitraje, el Ecuador ha pasado de no tener virtualmente arbitraje a ser un sistema absolutamente consolidado. No obstante, el camino recorrido no ha estado ajeno de amenazas, vacíos e inconsistencias. En el foro arbitral, luego de más de 20 años de expedida la Ley de Arbitraje y Mediación ("LAM"), existía un consenso general sobre la necesidad de una actualización normativa que de respuesta a esas amenazas, vacíos e inconsistencias. En este contexto, mediante Decreto Ejecutivo No. 165 de 18 de agosto de 2021, se expidió el Reglamento a la Ley de Arbitraje y Mediación (el "Reglamento") que por un lado, es una recopilación de las mejores prácticas en arbitraje que ya se habían consagrado en muchas decisiones de cortes y tribunales arbitrales, y, por otro lado, es un desarrollo progresivo de las normas legales en materia arbitral.

A lo largo de este trabajo, analizaremos los principales temas abordados por el Reglamento y, principalmente, nos enfocaremos en esclarecer los efectos de sus disposiciones. Para este fin, haremos un ejercicio integrativo con disposiciones ya existentes en el ordenamiento jurídico ecuatoriano y citaremos casos relevantes que ilustran la necesidad e importancia de la promulgación del Reglamento. Concluiremos que el Reglamento no ha hecho otra cosa sino, desarrollar la LAM, consolidar ciertas prácticas arbitrales $\mathrm{y}$ fomentar la institucionalización del sistema arbitral.

\section{LA NATURALEZA NEGOCIAL DEL ARBITRAJE Y SUPLENCIA DE LA NORMATIVA PROCESAL ORDINARIA}

Desde su concepción constitucional y posterior desarrollo legal, es incuestionable que el pilar angular del arbitraje es la autonomía de la voluntad de las partes. Esto, sin renegar de su raigambre jurisdiccional, lo convierte en una institución de carácter negocial. Esto, en palabras de la Corte Constitucional "[posibilita] el acceso a este mecanismo mediante un respaldo a la autonomía de las 
persona[s], [lo que] implica un pleno reconocimiento de un sistema 'alternativo' con normas y procedimiento propios" 2 .

En esta línea, la LAM consagra expresamente la aplicación concreta del principio de autonomía de la voluntad, por ejemplo, al reconocer que se puede optar entre un arbitraje: (i) administrados o ad-hoc, (ii) público o confidencial; (iii) con tribunales unipersonales o conformado por tres árbitros; (iv) en derecho o equidad ${ }^{3}$. Además, concretamente, respecto a facultad de las partes para acordar las normas procedimentales y alejarse de las normas rígidas de los procesos judiciales, el artículo 38 de la LAM prescribe que "[e]1 arbitraje se sujetará a las normas de procedimiento [determinadas] en el convenio arbitral o al que las partes escojan, sin perjuicio de las normas supletorias que sean aplicables" ${ }^{4}$.

Precisamente, esta característica -entre otras- diferencian al arbitraje de la justicia ordinaria, pues, sacando a la normativa procesal de la esfera clásica del Derecho público indisponible, “permite que las partes pacten y diseñen reglas que más convengan a su particular relación [generando un proceso] espontáneo: la ausencia de planificación, de rigidez y de inmutabilidad" ${ }^{\prime}$. Esta particular naturaleza del Derecho procesal arbitral ha sido ratificada por la Corte Constitucional, quien ha resuelto que "[d]ebido a su origen contractual, las partes gozan de amplia flexibilidad para determinar las reglas que consideren eficaces y adaptar la estructura del procedimiento en función de su naturaleza y complejidad" y "adaptar el procedimiento a las particularidades del caso concreto" 6 . De igual forma, los tribunales arbitrales han sido consistentes en reconocer la naturaleza negocial de las normas procesales en

2. Corte Constitucional del Ecuador, Caso No. 323-13-EP, Sentencia No. 323-13-EP/19, 19/11/2019, pp. 33-34.

3. Ley de Arbitraje y Mediación, Artículos. 2, 3, 5, 7, 10, 27, 34, RO No. 145, 04/09/1997.

4. Ley de Arbitraje y Mediación, N. 3, Artículo 38.

5. A. Galindo y H. Garcia, "Relación entre el Código Orgánico General de Procesos y el procedimiento arbitral", Revista Ecuatoriana de Arbitraje, No. 6, 2014, p. 56. Ver, B. CREMADES, "Consolidación de la Autonomía de la Voluntad en España: El Convenio Arbitral", Tratado de Derecho Arbitral Carlos Alberto Soto Coaguila El Convenio Arbitral, Instituto Peruano de Arbitraje, 2011, p. 665.

6. Corte Constitucional del Ecuador, Caso No. 2573-17-EP, Sentencia No. 2573-17-EP/21, 25/08/2021, pp.59-68. Ver, Corte Constitucional del Ecuador, Caso No. 177-15-EP, Sentencia No. $177-15-\mathrm{EP} / 20$. 
materia arbitral y la facultad que tienen las partes de diseñar su propio procedimiento ${ }^{7}$.

Ahora bien, esta facultad tampoco implica que las partes pueden, a guisa de invocar su libertad de configuración interna del negocio jurídico, hacer tabla llana con los principios fundamentales que garantizan el debido proceso arbitral. La autonomía de la voluntad y la libertad negocial también observan un límite en el orden público ${ }^{8}$. Así también lo han reconocido tanto la Corte Constitucional ${ }^{9}$ como los tribunales arbitrales $^{10}$.

Ahora, la pregunta de qué hacer cuando las partes han guardado silencio sobre un asunto procedimental ha generado, de alguna forma, una controversia menor. Un minoritario sector ha considerado que en estas circunstancias un tribunal arbitral se ve en la obligación de aplicar a raja tabla las disposiciones del Código General de Procesos ("COGEP"). Como veremos, nada más alejado de la realidad. Y es que el asunto de vacíos normativos durante el proceso arbitral se resuelve de manera simple: (i) con la potestad que tiene el tribunal arbitral para dirigir el proceso y

7. Proceso Arbitral CCQ No. 079-16, Árbitros: Francisco Santillán, Ernesto Albán y Marcos Ponce, Decisión de 29/03/2017: "En Ecuador la normativa procesal en el arbitraje es de naturaleza negocial. Según el artículo 38 de la LAM, un arbitraje en el Ecuador se rige (i) por la LAM, (ii) por las disposiciones de los Reglamentos pactados, (iii) el acuerdo de las partes o en su defecto la decisión de los árbitros, y, en silencio de lo anterior (iv) las normas supletorias, cuando sean aplicables". Proceso Arbitral Centro de Arbitraje y Mediación Cámara de Comercio de Ambato y Cámara de Comercio de Industrias de Tungurahua No. 004-2016, Árbitros: Hugo García Larriva, Nelly Paredes y Julio Paredes, Orden Procesal 6, 18/05/2017: "El artículo 38 de la LAM reconoce cuales son las fuentes normativas para regular un procedimiento arbitral: LAM, Reglamento, acuerdo de las partes, y, en lo que no esté previsto en estas disposiciones, las normas supletorias. Es importante notar que, al reconocer el artículo 38 de la LAM al acuerdo de las partes como una fuente normativa, se reconoce que la naturaleza jurídica de las normas procesales en el arbitraje es negocial y no de Derecho público. Esto está en la esencia del arbitraje pues es lo que le permite ser flexible y distinto a los procesos judiciales".

8. L. Parraguez, Régimen Jurídico del Contrato, Editorial Jurídica Cevallos, 2021, p. 101. Ver, Código Civil, Artículo 1477, RO No. Sup. No. 46, 24/06/2005.

9. Corte Constitucional del Ecuador, Caso No. 2573-17-EP, N. 6, p. 59: "Ahora, si bien es un mecanismo ágil, flexible y con reglas propias, se trata a la vez de un proceso en el cual se plantean y resuelven pretensiones. Por lo tanto, la voluntad de las partes encuentra sus límites en la observancia y respeto a principios rectores, principalmente, aquellos relacionados al debido proceso arbitral y sus garantías".

10. Proceso Arbitral Centro de Arbitraje y Mediación Cámara de Comercio de Ambato y Cámara de Comercio de Industrias de Tungurahua, No. 004-2016, N. 7: "Es importante notar que, al reconocer el artículo 38 de la LAM al acuerdo de las partes como una fuente normativa, se reconoce que la naturaleza jurídica de las normas procesales en el arbitraje es negocial y no de Derecho público.Esto está en la esencia del arbitraje pues es lo que le permite ser flexible y distinto a los procesos judiciales. Esto no quiere decir que estas normas negociales no observen un límite común al del Derecho Público, esto es, las garantías al debido proceso y el derecho a la defensa". 
(ii) un entendimiento adecuado de la supletoriedad de las normas procesales ordinarias.

Sobre el primer punto, la capacidad del tribunal arbitral para dictar normas de procedimiento para la conducción del arbitraje, esta potestad es simplemente una consecuencia natural del encargo de árbitro que las partes otorgan. Específicamente, es una potestad -y a la vez obligación- implícita que deviene de la naturaleza del contrato receptum arbitri que se entiende incorporado en el mismo por disposición de los artículos 1460 y 1562 del Código Civil. Esto pues, las partes -en razón de la confianza- confieren a los árbitros "potestades suficientes para dirimir su controversia y para establecer o delimitar las reglas bajo las cuales se regirá el procedimiento arbitral"11. Además que, bajo inspiración de la Ley Modelo CNUDMI ${ }^{12}$ y la Convención de Nueva York en el artículo $\mathrm{V}(1)(\mathrm{d})^{13}$, la LAM en su artículo 17 segundo párrafo reconoce expresamente la facultad del presidente del tribunal arbitral de sustanciar y dirigir el proceso.

Sobre el segundo punto, esto es, sobre la supletoriedad de las normas procesales ordinarias, la referencia que el artículo 37 de la LAM realiza debe entenderse en este contexto negocial de las normas procesales en materia de arbitraje. La mentada supletoriedad no conlleva, como algunos han sostenido, una obligatoriedad de aplicar el COGEP en el arbitraje, sino simplemente una oportunidad para que, frente a un vacío, aquellas normas supletorias se apliquen adaptadas a la realidad del arbitraje y siempre y cuando no contravengan su espíritu y principios. En palabras de la Corte Constitucional:

11. E. Carmigniani, C. Cepeda, "Implementación (parcial) en Ecuador de principios de la Ley Modelo CNUDMI, sobre arbitraje comercial. Retrospectiva histórica y necesidades", Revista Ecuatoriana de Arbitraje, No. 8, 2016, p. 357. Ver, E. PICAND ALBÓNICO, Arbitraje Comercial Internacional, Tomo I, Editorial Jurídica Chile, 2005, p. 324. Citado por C. CORONEL JONES, “Arbitraje y Procedimiento", Iuris Dictio, No. 11, USFQ, 2007, p. 38.

12. Ley Modelo CNUDMI sobre Arbitraje Comercial internacional de 1985 con las enmiendas aprobadas en 2006 (2008), Artículo 19(2): "la constitución del tribunal arbitral o el procedimiento arbitral no se han ajustado al acuerdo celebrado entre las partes".

13. Convención sobre el Reconocimiento y la Ejecución de las Sentencias Arbitrales Extranjeras, Nueva York, (1958), Artículo V(1)(d): “[a] falta de acuerdo, el tribunal arbitral podrá, con sujeción a lo dispuesto en la presente Ley, dirigir el arbitraje del modo que considere apropiado. Esta facultad conferida al tribunal arbitral incluye la determinación, admisibilidad, la pertinencia y el valor de las pruebas". 
En arbitraje no aplican con la misma rigurosidad las normas procesales que rigen en los procesos judiciales. En tal medida, cuando la LAM se remite a la ley procesal o esta aplica por supletoriedad, tal aplicación debe siempre adecuarse a los principios y a la naturaleza propia del arbitraje como mecanismo independiente y alterno a la justicia ordinaria ${ }^{14}$.

En este sentido, el Reglamento al plasmar en sus artículos 1 -numerales 3 y $4^{15}$ y $10^{16}$ (i) la naturaleza negocial de las normas procesales en arbitraje; (ii) la potestad de las partes de diseñar directamente su proceso y, en su ausencia; (iii) reconocer la potestad del tribunal arbitral para ordenar el procedimiento; (iv) aclarando que el COGEP no es directamente aplicable al arbitraje, solo ha desarrollado la habilitación legal existente codificando las decisiones y principios anteriormente mencionados.

\section{Arbitraje con el sector público}

Que una entidad pública pueda suscribir un convenio arbitral, sea al celebrar un contrato o en un momento posterior, no debería llamar la atención. En Ecuador, ese no es el caso. Desde el 2006 el arbitraje con el sector público fue objeto de trabas y hasta hostilidades. La ideologización del arbitraje llegó al punto de que, desde la propia Secretaría Jurídica del expresidente Rafael Correa, se emitió un oficio circular a las entidades públicas donde casi se proscribía el arbitraje. Si a esto se suma la rígida interpretación sobre el requisito de autorización previa que la Procuraduría General del Estado mantuvo

14. Corte Constitucional del Ecuador, Caso No. 2573-17-EP, N. 6, p. 59.

15. Reglamento a la Ley de Arbitraje y Mediación, "Art. 1.- En los arbitrajes regulados por la Ley de Arbitraje y Mediación se aplicarán los siguientes principios.- ... 3. En la interpretación y aplicación de las normas de la Ley de Arbitraje y Mediación y de este Reglamento, se tomará en cuenta la naturaleza negocial y flexible del arbitraje, así como sus principios, usos y prácticas. 4. Asimismo, las cuestiones que no estén expresamente previstas en la Ley de Arbitraje y Mediación o en este Reglamento, serán resueltas por el tribunal arbitral tomando en cuenta la naturaleza negocial y flexible del arbitraje, así como sus principios, usos y prácticas”, RO No. $524,26 / 08 / 2021$.

16. Reglamento a la Ley de Arbitraje y Mediación, N. 15: “Art. 10.- Libertad de regulación de las actuaciones.- 1. Las partes podrán pactar y determinar libremente las reglas procesales a las que se sujetará el tribunal arbitral en sus actuaciones, sea directamente o por referencia a un reglamento arbitral. A falta de acuerdo o en ausencia de una disposición aplicable, el tribunal arbitral decidirá las reglas que considere más apropiadas teniendo en cuenta las circunstancias del caso pudiendo para esto recurrir a los principios y prácticas de uso común en materia arbitral. 2. Supletoriamente, cuando no contravenga los principios del arbitraje y si el tribunal estimare oportuno, se podrán aplicar las disposiciones contenidas en el Código Orgánico General de Procesos". 
y los problemas constantes sobre la arbitrabilidad de los actos administrativos de ejecución contractual -entre otros-, el resultado es que el arbitraje con el sector público se volvió virtualmente inexistente. Las cifras hablan por sí solas. En el año 2016, de 53.692 procesos de contratación pública, solamente se autorizaron 3 convenios arbitrales ${ }^{17}$. El 2017 fue aún peor, de 53.399 procesos de contratación, solo se autorizó 1 convenio arbitral ${ }^{18}$. En el 2018 algo parecido, de 55.897 proceso solo 3 convenios arbitrales autorizados ${ }^{19}$. En el 2019 algo mejoraron, de 47.293 procesos, 17 aprobaciones de arbitraje ${ }^{20}$. Tal vez el mejor año fue el 2020 donde se aprobaron 31 convenios arbitrales en 40.910 procesos de contratación ${ }^{21}$. En total, de 251.191 procesos contractuales desde el 2016, únicamente se aprobaron 55 convenios arbitrales. Eso quiere decir que la cantidad de convenios arbitrales autorizados no llega ni al 0,022\% de los contratos suscritos por entidades públicas dentro del Sistema Nacional de Contratación Pública. Si ampliásemos la data -que no la tenemos- a los contratos que se firman fuera de ese sistema, el panorama sería, francamente, más patético, por decir algo.

Para que el arbitraje con el sector público resurja era necesario una alineación normativa clara que, además, permee como un mensaje directo a la administración pública: el arbitraje no es el enemigo. En este contexto, el Reglamento viene a dar nuevos aires en la materia, particularmente en relación a (i) el uso del arbitraje en disputas relacionadas a contratos públicos; (ii) la arbitrabilidad objetiva en contratación administrativa; y, (iii) la autorización previa del Procurador General del Estado para suscribir convenios arbitrales.

\subsection{Suscripción de convenios arbitrales con el sector público}

Sin arbitraje toda disputa contractual con el sector público termina en la justicia ordinaria, específicamente en los ya de por sí congestionados Tribunales de lo Contencioso Administrativo. Esto genera al menos cuatro serias consecuencias. Primero, que los costos

17. Fuente, Portal del Servicio Nacional de Contratación Pública y información sobre aprobación de convenios arbitrales para arbitraje doméstico de la Procuraduría General del Estado.

18. Ídem.

19. Ídem.

20. Ídem.

21. Ídem. 
relacionados con el proceso de resolución de esas disputas no sean externalizados en quien mejor puede soportarlo -el privado-, sino que sean cargados a los escasos recursos que el Estado destina para la administración de justicia y que bien podrían liberarse para que la Función Judicial atienda casos con mayor sensibilidad e impacto social. Segundo, sobrecarga de trabajo a la justicia administrativa cuya esencia no es resolver disputas de carácter contractual, sino proteger a los ciudadanos frente a los abusos y desviaciones del poder público ${ }^{22}$. Tercero, esta sobrecarga genera innecesarias demoras que tienen nefastos efectos. Por ejemplo, la tardía tutela de un derecho de un administrado que se ve afectado por un acto ilegítimo de poder público. Cuarto, la sobrecarga y consecuente demora genera, además, inexcusables costos transaccionales para el Estado y los administrados. No es ciencia oscura el hecho de que el dinero en el tiempo tiene un costo. En este sentido, mientras más se demora el Estado o el administrado en resolver una disputa contractual que en esencia es patrimonial, mayores costos transaccionales se generan. Si el Estado tiene la razón, es mejor que se la den rápido. Si el administrado tiene la razón, no hay motivo de demorar la reparación de su derecho subjetivo. Una decisión tardía solo implica más perjuicios para quien tiene la razón, perjuicios que si se los genera al administrado debe pagar el Estado, o mas bien, todos lo ciudadanos con los impuestos que pagamos.

Las anteriores razones -entre otras- justifican que el Estado promueva el que las disputas contractuales de las entidades públicas sean resueltas mediante arbitraje. El Estado así lo ha entendido y a través de la reforma a la Ley Orgánica para el Fomento Productivo, Atracción de Inversiones, Generación de Empleo, Estabilidad y Equilibrio Fiscal (la "Ley de Fomento Productivo") que reformó el COPCI se añadió el artículo innumerado primero luego del artículo 16 que dispone "[e]l estado ecuatoriano deberá pactar arbitraje nacional para resolver disputas generadas a través de contratos de inversión, de conformidad con la Ley". El Reglamento, en esta misma línea, (i) promueve expresamente que los pliegos contractuales contemplen la posibilidad de arbitraje $^{23}$ y (ii) que en aquellos

22. Es importante recordar que solo recientemente los Tribunales de lo Contencioso Administrativo asumieron competencia para conocer disputas relacionadas con la responsabilidad civil de las entidades públicas. Antes lo conocían los jueces de lo civil. Ver Ley de la Jurisdicción Contencioso Administrativa, Artículo 6(b), RO No. 338, 18/03/1968 (derogada).

23. Reglamento a la Ley de Arbitraje y Mediación, N. 15, Disposición transitoria cuarta. 
contratos que ya se han suscrito, se incorpore un convenio arbitral. Sobre el segundo punto, es importante detenerse un poco sobre el proceso que debe seguirse para suscribir dicho convenio arbitral y la consecuencia de la inacción de los funcionarios administrativos. El artículo 5(1) del Reglamento reza:

Cuando en el contrato no se hubiere pactado arbitraje, el contratista podrá solicitar a la entidad contratante la suscripción de un convenio arbitral para que un tribunal de arbitraje resuelva las diferencias existentes o futuras que tengan relación con dicho contrato. La entidad deberá responder a la solicitud en el término máximo de treinta (30) días. Dentro del mismo término, las partes podrán negociar el contenido del convenio arbitral. Si la entidad no da respuesta a la solicitud en el tiempo establecido en este artículo, $\underline{\text { se entenderá que ha aceptado el convenio arbitral propuesto por la }}$ contratista.

Si bien en materia negocial el silencio no conlleva una declaración afirmativa o negativa de la voluntad, sino manifiesta ausencia de la misma, una norma jurídica sí que puede calificarlo y otorgarle un valor, sea de aceptación o de negativa. Esto es lo que precisamente hace el Reglamento, califica al silencio de la administración y le da una consecuencia específica: la aceptación presunta del convenio arbitral. Esto genera un consentimiento tácito por parte de la administración pública cuyo efecto negocial no es otro que el perfeccionamiento del convenio arbitral. Ahora, cuando el convenio arbitral requiera aprobación del Procurador General del Estado, bastaría que el administrado solicite dicha aprobación fundamentado en el consentimiento presunto de la entidad pública para que se proceda con dicha autorización.

\subsection{Arbitrabilidad en disputas con el sector público}

LaprincipalconsecuenciadequelaConstituciónylaLeyhabiliten pactar arbitraje con el sector público es que en esta sede puedan resolverse todas las controversias que se encuentren relacionadas con un contrato en específico. Dado que la administración pública solo puede interactuar en una relación contractual a través de actos o hechos administrativos, es solo natural que las disputas a ser resueltas en arbitraje giren, entonces, alrededor de la validez o 
juridicidad de dichos actos y las consecuencias -económicas o noque despliegan en el contrato. Así enmarcada la cosa, no puede sino entenderse que la habilitación constitucional para pactar arbitraje en contratos con el sector público conlleva necesariamente una habilitación para que los árbitros puedan resolver sobre la legalidad de los actos administrativos de naturaleza contractual. De no ser así, dicha habilitación -la de pactar arbitraje- quedaría vaciada de contenido pues muy difícilmente encontraremos disputas que no envuelvan de una $\mathrm{u}$ otra forma actuaciones administrativas dentro de la relación contractual ${ }^{24}$. Así lo ha entendido con unanimidad la doctrina ecuatoriana ${ }^{25}$.

Sin embargo, no son pocos los casos en los que las entidades públicas -tanto en sede arbitral como al interponer diferentes recursos- han alegado que al resolver los árbitros sobre la base de actos administrativos de ejecución contractual, estos han excedido la competencia que el ordenamiento jurídico les otorga. Lamentablemente esta posición no ha dejado de tener eco en decisiones aisladas de tribunales y cortes. La principal falacia usada para objetar dicha competencia era que dado que los actos administrativos son resultado de un ejercicio de una potestad administrativa que no puede ser objeto de transacción, estos -los actos- son inarbitrables. Mezclar la causa eficiente - potestad-con el resultado -acto administrativo- es absurdo. Cuando un árbitro resuelve sobre la legalidad de un acto administrativo no está "transigiendo" sobre una potestad pública. La potestad pública está y sigue ahí, inalterada. Lo único que se realiza es el control de legalidad del ejercicio de dicha potestad. Esta tarea es la misma que realizaría un juez ordinario y a nadie se le ocurriría insinuar

24. Proceso Arbitral CIAM No. 001-2020, Decisión de competencia, 10/11/2021, pp. 194, 195: "Nótese que, si se siguiera la línea interpretativa propuesta por la Demandada, no se llega a advertir qué tipo de disputas podrían las Partes someter a arbitraje conforme a lo que ellas mismas convinieron en la cláusula 68 del Contrato. Siendo [la entidad estatal demandada] una persona jurídica de derecho público, de seguirse aquella interpretación (que el Tribunal no comparte) su actuación durante la ejecución del Contrato se exteriorizará a través de actos y conductas que, cualquiera sea su calificación (actos administrativos, actos de la Administración o meros pronunciamientos administrativos o hechos administrativos) quedarían excluidos de la jurisdicción arbitral previamente pactada, lo que contradice el texto claro de la cláusula 68 del Contrato. El Tribunal entiende que una interpretación de buena fe de la referida cláusula -principio rector tanto para los contratos privados como los públicos- es aquella que permite darle pleno efecto al acuerdo de las Partes, sin vaciarlo de contenido".

25. Ver J. P. Aguilar, "Derecho Administrativo y transigibilidad", Revista Ecuatoriana de Arbitraje, No. 6, 2014. F. LaRreA, "Arbitrabilidad de Actos Administrativos Contractuales", Revista Ecuatoriana de Arbitraje, No. 7, 2014. 
que el Tribunal Contencioso Administrativo está, de alguna forma, transigiendo con las potestades públicas.

El análisis es más simple. La arbitrabilidad de los actos administrativos surge de la habilitación constitucional y legal para conocer disputas en materia de contratación con el sector público ${ }^{26}$. Simple. Además, no solo la constitución y la ley consagran dicha habilitación, sino que existe todo un corpus normativo al respecto:

a) El artículo 71 de la Ley Orgánica del Sistema Nacional de Contratación Pública manda que: "[1]as multas impuestas al contratista pueden ser impugnadas en sede administrativa, a través de los respectivos recursos, o en sede judicial o arbitral" $^{\prime 27}$.

b) La Codificación de Resoluciones del Servicio de Contratación Pública prevé en su artículo 48(2) que:

Art. 48.- Rehabilitación del incumplimiento.- La compañía o empresa de seguros, banco o institución financiera declarada como incumplida, podrá rehabilitarse y en esa medida ser excluida del Registro de Incumplimientos, en los siguientes casos: $[\ldots]$

2. Que exista sentencia ejecutoriada, resolución de órgano judicial competente, acta de acuerdo de mediación o laudo arbitral que deje sin efecto el acto administrativo que originó la inclusión en el Registro de Incumplimientos $[\ldots]^{28}$.

c) El Código Orgánico de la Producción, Comercio e Inversión ("COPCI") expresamente reconoce que los actos administrativos de ejecución contractual relacionados con el (in)cumplimiento y resolución de contratos administrativos son arbitrables:

En el caso en el que el Estado pacte arbitraje internacional en derecho, el contrato de inversión hará referencia a que toda controversia resultante de la inversión o del contrato, su incumplimiento, resolución o nulidad, será resuelta, a

26. J. P. Aguilar, N. 25, pp. 261-262. F. Larrea, N. 25, p. 288.

27. Ley Orgánica del Sistema Nacional de Contratación Pública, RO Sup. No. 395, 04/08/2008.

28. Codificación Resoluciones del Servicio Nacional de Contratación Pública, Artículo 71, RO Ed. Esp. 245, 29/01/2018. 
elección del reclamante, mediante arbitraje ${ }^{29}$.

Adicionalmente, la justicia administrativa ha confirmado que los tribunales arbitrales gozan de competencia exclusiva para conocer la impugnación de actos administrativos de ejecución contractual. El Tribunal de lo Contencioso Administrativo con sede en Cuenca en dos casos de manera clara ha resuelto que:

Surgida la controversia no existe a juicio del juzgador otra vía que el someter el acto administrativo dictado por el Gerente General del FISE, terminación unilateral anticipada del contrato a la instancia pactada en el convenio, que no es otra que el sistema de arbitraje y al Centro de Arbitraje y Mediación de la Cámara de Comercio de la ciudad de Quito ${ }^{30}$.

Estos pronunciamientos fueron ratificados por la Corte Nacional de Justicia resolviendo que "no existe el vicio alegado por el recurrente por cuanto la cláusula vigésimo tercera del contrato suscrito el 30 de junio de 2004, establece con claridad el sometimiento a arbitraje de las controversias surgidas en razón del mismo" ${ }^{\prime \prime}$.

Las normas y pronunciamientos judiciales citados van en línea también con lo que los tribunales arbitrales han resuelto. Por ejemplo, en el caso Fondo de Inversión Social de Emergencia FISE en contra de la Fundación Centro de Planificación y Estudios Sociales CEPLAES, el tribunal arbitral resolvió:

Es imprescindible tener presente que si bien la declaración de resolución anticipada y unilateral del contrato es un acto unilateral de naturaleza administrativa porque supone el ejercicio de las facultades de que está investida la administración respecto del contrato administrativo por ella celebrado, es en todo caso un acto administrativo que está íntimamente vinculado a la relación jurídica contractual en la que incide de modo decisivo, pues se trata de una facultad que nace con tal contrato y sigue su suerte hasta que desaparece

29. Código Orgánico de la Producción, Comercio e Inversiones, tercer artículo innumerado luego del artículo 16, RO Sup. No. 351, 29/12/2010.

30. Tribunal Distrital de lo Contencioso Administrativo con sede en la Ciudad de Cuenca, Procesos No. 295-2007, 07/07/2009 y No. 296, 21/09/2009.

31. Corte Nacional de Justicia, Recurso de casación No. 493-2009, 31/10/2012. Ver Corte Nacional de Justicia, Recurso de casación No. 387-2009, 01/11/2012. Ver además, Corte Provincial de Pichincha, Proceso No. 17113-2014-2362, 14/01/2020. 
con la extinción o terminación del contrato administrativo al cual se halla indisolublemente ligado. Si la Constitución y la ley permiten y facultan que las controversias derivadas de los contratos que celebra la administración pública se ventilen en arbitraje, no es lógico ni jurídicamente admisible que de la controversia se aísle el acto administrativo que da por terminado unilateral y anticipadamente el contrato, porque se fracturaría la continencia de la causa en perjuicio de la paz social, de la correcta administración para dar por terminado el contrato, si la controversia surgida entre las partes radica o nace precisamente de tal decisión y las partes expresamente y por permisión constitucional y legal, convinieron en resolver por arbitraje sus controversias nacidas del contrato. En síntesis, el momento en que se suscribe un convenio arbitral en un contrato celebrado por la administración pública, de conformidad con lo previsto por los artículos 7 y 8 de la Ley de Arbitraje y Mediación, pierden competencia para conocer de las controversias relacionadas con tal contrato, los jueces de lo Contencioso Administrativo. Si la Constitución de la República y la ley amparan la posibilidad de que en los contratos administrativos se pueda convenir arbitraje como el medio idóneo para solucionar las controversias que por tal contrato se presenten entre las partes, [...] obvio es considerar que el Tribunal Arbitral está plenamente autorizado por el ordenamiento jurídico para determinar si un acto administrativo ligado a la relación contractual, como el que es materia del presente proceso arbitral, es conforme o disconforme con el Derecho. En suma, si la Constitución y la Ley amparan la posibilidad de que en los contratos administrativos se pueda convenir en arbitraje, esto implica que los árbitros se hallan facultados para que en arbitraje pueda dejarse sin efecto la decisión administrativa que termina unilateralmente el contrato ${ }^{32}$.

En este sentido, el Reglamento en su artículo 4, tercer inciso ${ }^{33}$, al reconocer la arbitrabilidad de los actos administrativos únicamente

32. Proceso Arbitral CCQ No. 077-09, Laudo, 06/07/2011, p. 8.2.

33. Reglamento, No. 15: "Si el Estado o una entidad del sector público hubiese pactado arbitraje, los árbitros tendrán competencia exclusiva para resolver cualquier disputa sobre los hechos, actos o demás actuaciones administrativas que tengan relación o surjan con ocasión de la relación jurídica sometida a su conocimiento, incluyendo los actos de terminación, caducidad, o sancionadores expedidos en el marco de la relación jurídico contractual, indistintamente del órgano administrativo que los emita". 
desarrolla los principios consagrados en la normativa vigente $\mathrm{y}$, por otro lado, codifica las decisiones de tribunales y cortes.

\subsection{La autorización del Procurador General del Estado}

La autorización del Procurador General del Estado para que entidades públicas puedan suscribir convenios arbitrales no es de reciente cuño. De hecho, antes de la promulgación de la Constitución de 2008, tanto la LAM como la Ley Orgánica de la Procuraduría General del Estado ya la contemplaban en dos casos: el primero, cuando el convenio arbitral se suscribe con posterioridad al surgimiento de la disputa ${ }^{34} ; \mathrm{y}$, el segundo, cuando el arbitraje sea de carácter internacional, salvo que este mecanismo estuviere previsto en instrumentos internacionales ${ }^{35}$. La Ley Orgánica de la Procuraduría General del Estado En esta materia la Constitución de 2008 no agregó nada, por lo que la referencia a "conforme las condiciones establecidas en la ley" que realiza el segundo párrafo del artículo 190 al tratar la autorización previa del Procurador General del Estado no puede sino entenderse a los dos supuestos señalados antes ${ }^{36}$.

Pese a lo anterior, parte del foro ecuatoriano ha sostenido constantemente que el artículo 190 de la Constitución obliga en todos los casos a requerir autorización previa para suscribir convenios arbitrales en contratos regulados por la Ley Orgánica

34. Ley de Arbitraje y Mediación, No. 3, Artículo 4: "Podrán someterse al arbitraje regulado en esta Ley las personas naturales o jurídicas que tengan capacidad para transigir, cumpliendo con los requisitos que establece la misma. Para que las diferentes entidades que conforman el sector público puedan someterse al arbitraje, además de cumplir con los requisitos que establece esta Ley, tendrán que cumplir los siguientes requisitos adicionales: a) Pactar un convenio arbitral, con anterioridad al surgimiento de la controversia; en caso de que se quisiera firmar el convenio una vez surgida la controversia, deberá consultarse al Procurador General del Estado, dictamen que será de obligatorio cumplimiento [...]”. Ley Orgánica de la Procuraduría General del Estado, Artículo 11(2): "Surgida la controversia, los organismos y entidades del sector público pueden someterse a arbitraje de derecho o mediación, de conformidad con las leyes pertinentes. Para someterse al arbitraje internacional requerirán además la autorización de la Procuraduría General del Estado", RO No. 312, 13/04/2004.

35. Ley de Arbitraje y Mediación, No. 3, Artículo 42: "Para que las diferentes entidades que conforman el sector público puedan someterse al arbitraje internacional se requerirá la autorización expresa de la máxima autoridad de la institución respectiva, previo el informe favorable del Procurador General del Estado, salvo que el arbitraje estuviere previsto en instrumentos internacionales vigentes". Ley Orgánica de la Procuraduría General del Estado, No. 34, Artículo 11(2).

36. E. NeIRA, "La Constitución de 2008 y el arbitraje bajo la ley ecuatoriana: análisis de dos problemas que surgen antes que del texto constitucional, de su equivocada aplicación", Revista Ecuatoriana de Arbitraje, No. 3, 2011. 
del Servicio Nacional de Contratación Pública y, por fuera de estos, cuando el arbitraje sea de carácter internacional. Esta posición ha sido sostenida con particular vehemencia por la Procuraduría General del Estado ${ }^{37}$. Sin embargo, como lo veremos, (i) esta tesis no tiene sustento en el ordenamiento jurídico ecuatoriano y (ii) ha sido rechazada por cortes y tribunales arbitrales.

Sobre el primer punto, es importante regresar al texto del artículo 190 de la Constitución que condiciona la exigibilidad de la autorización del Procurador General del Estado a "las condiciones establecidas en la ley". Como vimos estas son dos -existencia de la disputa de manera previa y carácter internacional de la controversia-. Varias disposiciones del ordenamiento jurídico así lo confirman:

a) El artículo 11 de la Ley Orgánica de la Procuraduría General del Estado prescribe:

Los organismos y entidades del sector público podrán someterse a procedimientos de arbitraje de derecho y a la mediación nacional o internacional, de acuerdo con lo establecido en la Ley de Arbitraje y Mediación, o en instrumentos internacionales que los faculte, previa la suscripción del respectivo convenio ${ }^{38}$.

b) El artículo 162 del Reglamento de la Ley Orgánica del Sistema Nacional de Contratación Pública prevé:

Cuando en el contrato no se hubiere pactado cláusula compromisoria, cualquiera de las partes podrá solicitar a la otra la suscripción de un compromiso o convenio arbitral para que un Tribunal de Arbitraje resuelva las diferencias presentadas en razón de la celebración del contrato y su ejecución, desarrollo, terminación. En este caso, se requerirá informe favorable previo de la Procuraduría General del

37. Por ejemplo, la Procuraduría General del Estado en sus oficios circulares No. 09258 y 10623 alegaba que "Se requiere el pronunciamiento previo de la Procuraduría General del Estado, para proceder a la suscripción de todo convenio arbitral, en materias reguladas por la Ley Orgánica del Sistema Nacional de Contratación Pública" y "De no solicitarse la autorización prevista en el artículo 190 de la Constitución Política de la República en el plazo previsto, y siendo dicha autorización un requisito esencial para la validez del convenio arbitral, tales convenios estarán sujetos a las consecuencias legales que esta omisión acarrea".

38. Ley Orgánica de la Procuraduría General del Estado, No. 34, Artículo 11. 
Estado. En el documento de compromiso o convenio arbitral que se suscriba se señalará la materia objeto del arbitraje, la designación de árbitros, el lugar de funcionamiento del tribunal y la forma de cubrir los costos del mismo ${ }^{39}$.

c) El artículo 2 del “Instructivo para solicitar al Procurador General del Estado, autorización para el sometimiento a Arbitraje Nacional, Internacional, Ley y Jurisdicción Extranjeras" determina que:

En los casos en los que no se haya pactado el sometimiento a arbitraje, sin importar la naturaleza de la relación contractual, una vez surgida la controversia, los organismos y entidades del sector público que vayan a someter la controversia a arbitraje, deberán solicitar previamente autorización al Procurador General del Estado ${ }^{40}$.

Sobre el segundo punto, esto es, sobre las decisiones que han rechazado la tesis de la Procuraduría General del Estado, vale la pena señalar dos ejemplos. El primero es un proceso de nulidad sustanciado ante el Presidente de la Corte Provincial de Manabí, donde las alegaciones de nulidad de laudo arbitral por falta de autorización del Procurador General del Estado fueron rechazadas de plano:

De lo anotado podemos determinar con estricta claridad que en el evento de suscribirse un contrato con una institución pública, se puede establecer una cláusula arbitral sin necesidad de que la Procuraduría General del Estado brinde su autorización, siendo necesaria tal autorización únicamente cuando se ha suscitado una controversia y se busca que el proceso sea sometido a arbitraje; o, cuando se trate de someterse al arbitraje internacional. [...]

Respecto a todas estas alegaciones, es necesario esclarecer que el legislador ha previsto que la acción de nulidad de laudo arbitral se encuentra limitada a los supuestos taxativamente señalados en el artículo 31 de la Ley de Arbitraje y Mediación; por lo tanto al no haberse previsto por el legislador a la "falta de motivación", "la incompetencia", "la falta de Legítimo

39. Reglamento a la Ley Orgánica del Sistema Nacional de Contratación Pública, Artículo 162, RO Sup. No. 588, 12/05/2009.

40. Procuraduría General del Estado, Resolución No. 122, Artículo 2, 07/05/2014. 
Contradictor"; "la indebida acumulación de acciones; ni la "Prescripción" como causas para sustentar la acción de nulidad de laudo arbitral, esta autoridad se halla impedida de revisar por esta vía tales alegaciones ${ }^{41}$.

El segundo ejemplo que vale la pena traer a colación es la decisión sobre jurisdicción y competencia del tribunal arbitral conformado por los doctores Luis Parraguez Ruiz, Alfredo Corral Borrero e Íñigo Salvador Crespo -actual Procurador General del Estado-, que, frente a una objeción por inexistencia de la aprobación previa del Procurador General del Estado, concluyó que:

Del texto transcrito [Artículo 190 de la Constitución] se desprende que en ambos incisos dicha norma constitucional se remite a la ley. La expresión utilizada en el inciso segundo, "conforme a las condiciones establecidas en la ley", la entiende el Tribunal referida a la Ley de Arbitraje y Mediación [...]

Así, pues, el inciso segundo del artículo 4 de la Ley de Arbitraje y Mediación distingue dos situaciones muy diferentes: la primera, relativa a los convenios arbitrales pactados con anterioridad al surgimiento de la controversia (lo resaltado es énfasis del Tribunal), como es el presente caso en el que el convenio arbitral se pactó en el mismo contrato de fecha 20 de noviembre. de 2008); la segunda, que se refiere a los convenios pactados una vez surgida la controversia (lo resaltado es énfasis del Tribunal), que según la norma legal transcrita requieren la consulta y dictamen del Procurador General del Estado $[\ldots]^{42}$.

Así, el Reglamento, nuevamente, ha desarrollado la habilitación legal y codificado las decisiones existentes en la materia, confirmando en su artículo 4(2) que solo se requiere autorización previa del Procurador General del Estado para suscribir un convenio arbitral en dos circunstancias: cuando ya ha surgido la controversia o cuando el arbitraje sea de carácter

41. Presidencia de la Corte Provincial de Manabí, Proceso No. 13100-2019-00005, 06/01/2020. Ver además, los siguientes casos en los que tampoco prosperó la acción de nulidad propuesta por el Estado: (i) Proceso No. 17100-2013-0054 en el que el entonces Instituto Ecuatoriano de Propiedad Intelectual alegó incompetencia del tribunal arbitral; y, (ii) Proceso No. 17100-201500013 en el que la entonces Superintendencia de Bancos y Seguros y la Procuraduría General del Estado alegaron incompetencia del tribunal arbitral y también invocaron la causal d) del artículo 31 de la LAM por incongruencia de extra petita.

42. Proceso Arbitral CIAM No. 006-2017, Acta de Audiencia de Sustanciación, 18/05/2018. 
internacional, salvo que este mecanismo estuviere previsto en instrumentos internacionales, como sería el caso, por ejemplo, de una cláusula arbitral que establezca arbitraje administrado por el Centro Internacional de Arreglo de Diferencias Relativas a Inversiones ("CIADI"), creado al amparo del Convenio sobre Arreglo de Diferencias Relativas a Inversiones entre Estados y Nacionales de otros Estados ("Convenio CIADI").

\section{LA ACCIÓN DE NULIDAD DE LAUDOS ARBITRALES}

El artículo 31 de la LAM prevé que cualquier parte podrá interponer la acción de nulidad en contra del laudo dictado conforme a los siguientes términos:

Art. 31.- Cualquiera de las partes podrá intentar la acción de nulidad de un laudo arbitral, cuando: [...]

a) No se haya citado legalmente con la demanda y el juicio se ha seguido y terminado en rebeldía. Será preciso que la falta de citación haya impedido que el demandado deduzca sus excepciones o haga valer sus derechos y, además, que el demandado reclame por tal omisión al tiempo de intervenir en la controversia;

b) No se haya notificado a una de las partes con las providencias del tribunal y este hecho impida o limite el derecho de defensa de la parte;

c) Cuando no se hubiere convocado, no se hubiere notificado la convocatoria, o luego de convocada no se hubiere practicado las pruebas, a pesar de la existencia de hechos que deban justificarse;

d) El laudo se refiera a cuestiones no sometidas al arbitraje o conceda más allá de lo reclamado; o,

e) Cuando se hayan violado los procedimientos previstos por esta Ley o por las partes para designar árbitros o constituir el tribunal arbitral.

Por muchos años, existió una discusión sobre la taxatividad o no de las causales de nulidad del artículo 31 de la LAM. Por 
un lado, se alegaba que los casos previstos por el legislador eran numerus clausus. Por otro, se argumentaba que los laudos arbitrales no estaban exentos del cumplimiento de otras normas y garantías constitucionales, luego, cabía interponer la acción de nulidad por otros motivos como la falta motivación, seguridad jurídica, falta de competencia, entre otros.

La contraposición de posturas se incrementó con la expedición de decisiones contradictorias no solo entre presidencias de Cortes Provinciales del país, entre decisiones de la Presidencia de una misma Corte Provincial, pero además, por fallos de la Corte Constitucional ${ }^{43}$.

Por fortuna, la nueva Corte Constitucional zanjó la discusión existente a través de las sentencias 323-13-EP/19 y 0031-14-EP/19, en las cuales expresamente expuso, respectivamente, que:

La taxatividad de estas causales de nulidad se justifica en que esto brinda certeza en torno las exactas situaciones jurídicas que podrían suponer la anulación de una decisión que, al tener efectos de cosa juzgada, ha generado una legítima confianza en las partes procesales sobre determinada situación jurídica. Es por esto que, en materia de nulidades procesales, rige el principio de especificidad, principio que implica que: no hay nulidad sin texto; no hay nulidad sin ley ${ }^{44}$.

En la ley deben establecerse expresamente aquellos motivos por los cuales una autoridad judicial está habilitada para militar una decisión que goza de cosa juzgada y que, por tanto, ha generado en las partes procesales una certeza sobre determinada situación jurídica.

La nulidad del laudo es una sanción y como sucede con toda sanción, la infracción que la genera debe estar establecida expresamente en la ley, conforme lo establece el numeral 6 del artículo 76 de la CRE [...].

Las causales no expresamente previstas en la ley, no pueden ser objeto de revisión dentro de la acción de nulidad, pues la competencia del juez que conoce dicha acción se encuentra

43. Corte Constitucional del Ecuador, Caso No. 0080-13-EP, Sentencia No. 302-15-SEP-CC, 16/09/2015.

44. Corte Constitucional del Ecuador, Caso No. 323-13-EP, N. 2, p. 32. 
limitada por las cinco causales taxativamente contenidas en la ley de la materia ${ }^{45}$.

No cabe duda entonces que las causales de nulidad bajo el derecho ecuatoriano se reducen a aquellas contempladas en el artículo 31, pues esto garantiza el principio de intervención judicial mínima en el arbitraje. En palabras de la Corte:

A este respecto, es preciso que la Corte Constitucional efectúe una aclaración, pues la sentencia constitucional No. 302-15-SEP-CC, determinó que existió vulneración de derechos por parte del juzgador de justicia ordinaria dentro de una acción de nulidad de laudo, por considerar que la falta de competencia y de motivación constituyen causales de nulidad que, aunque no están expresamente contempladas en el artículo 31 de la LAM, deben ser analizadas de oficio durante cualquier acción de nulidad.

$[\ldots]$

Sin embargo, este Organismo se aparta de este criterio (incompetencia y falta de motivación como causales de nulidad) por cuanto este atenta contra la taxatividad que tienen las causales de la acción de nulidad y que constituyen un efecto del principio de intervención judicial mínima que precisamente limita la interferencia injustificada de la justicia ordinaria en el arbitraje ${ }^{46}$.

Ahora, hemos sido específicos al hablar de que la taxatividad de las causales de nulidad bajo el derecho ecuatoriano se limitan a aquellas contempladas en el artículo 31 de la LAM, pues a nivel comunitario existe una causal adicional que ha sido introducida por el Tribunal Andino de Justicia: la falta de interpretación prejudicial de la normativa andina ${ }^{47}$. Pese a ser un asunto que merece un mayor análisis, el contenido ni los contornos de la causal de nulidad comunitaria son objetos de este estudio por lo que, a continuación, analizaremos las disposiciones del Reglamento respecto a [\$ 4.1.]

45. Corte Constitucional del Ecuador, Caso No. 0031-14-EP, Sentencia No. 0031-14-EP/19, 19/11/2019, p. 48.

46. Corte Constitucional del Ecuador, Caso No. 323-13-EP, N. 2, pp. 31-32.

47. Ver, entre otros, Proceso 03-AI-2010, Acción de incumplimiento interpuesta por la Empresa de Telecomunicaciones de Bogotá S.A. ESP, (ETB S.A. E.S.P) c. la República de Colombia, Sección Tercera del Consejo de Estado, pp. 34-35. 
los principios aplicables a la sustanciación de este proceso y [§ 4.2.] el trámite a seguirse.

\subsection{Principios aplicables al procedimiento de nulidad}

El Reglamento llega para aportar al desarrollo de la figura de la nulidad del laudo arbitral en nuestro país, al determinar cuáles son los principios que rigen a esta acción. El artículo 13 del Reglamento establece que:

1. Para resolver la acción de nulidad se deberán observar los principios de alternabilidad del arbitraje, mínima intervención, especificidad, conser-vación, convalidación, preclusión y trascendencia, en particular:

a. Que la parte afectada haya reclamado de manera inequívoca y oportuna al tribunal arbitral al momento de la ocurrencia del hecho o actuación que genera el reclamo.

b. Que la anulación se circunscribirá a los pronunciamientos del laudo afectados por la causal de nulidad, siempre que estos puedan separarse de los demás, caso contrario, la anulación será total.

c. Que en caso de duda, deberá preferirse la validez del laudo.

d. Que la mera existencia de una causal sin que exista perjuicio cierto e irreparable no genera nulidad.

e. Que no procede la anulación del laudo si la causal que se invoca ha podido ser subsanada en el proceso y la parte interesada no cumplió con solicitarlo.

En términos generales, esta norma codifica y desarrolla los principios generales de la nulidad procesal y el de mínima intervención jurisdiccional en el arbitraje. Busca que la declaratoria de nulidad del laudo arbitral sea de ultima ratio, garantizando así no solo la decisión tomada por los árbitros, pero además, el sistema arbitral en su conjunto, y, el derecho constitucional de las partes de ser juzgadas por la autoridad que han escogido, con todo lo que ello implica. Veamos brevemente a qué se refieren estos principios. 
Respecto al principio de mínima intervención de los jueces ordinarios en la justicia arbitral, la Corte Constitucional ha dicho que debido al "reconocimiento constitucional a la naturaleza convencional y alternativa del arbitraje, su efectividad también depende de un deber de respeto e independencia por parte de la justicia ordinaria hacia el arbitraje" ${ }^{\prime 8}$. Sobre el principio de especificidad, ya observamos que la Corte Constitucional to ha resumido en que "no hay nulidad sin ley"49.

En palabras de Edgar Neira Orellana, la alternabilidad del arbitraje emana del reconocimiento del arbitraje como mecanismo alternativo de solución de controversias de la Constitución y la definición de arbitraje del artículo 1 de la LAM, y:

[S]e predica del arbitraje como tal, esto es, del sistema arbitral en su conjunto, sin excluir a ninguno de los elementos que lo conforman: los árbitros, el procedimiento y el laudo que pone fin a la controversia, son los elementos sistémicos que integran el arbitraje y vienen investidos todos ellos de alternabilidad respecto de los jueces, cortes y tribunales, del procedimiento civil y del régimen de impugnación de los decretos, autos y sentencias que expiden los jueces ${ }^{50}$.

En lo que respecta al principio de conservación, se busca salvaguardar no solo el convenio arbitral pactado por las partes, pero también el proceso arbitral derivado de este acuerdo, y consecuentemente, el laudo dictado por los árbitros. María Elena Jara dice al respecto que:

[N]os referiremos en lo posterior al principio favor arbitri o favor arbitralis, como una directriz que orienta la formulación y la aplicación de normas que en última instancia precautelan el derecho a tutela efectiva de los ciudadanos mediante la conservación de la vigencia del convenio arbitral o del laudo

48. Corte Constitucional del Ecuador, Caso No. 323-13-EP, N. 2, p. 34.

49. Ídem, p. 28. Ver adicionalmente, O. SAntos DÁvalos, "La Acción de nulidad de los laudos arbitrales", Revista Ecuatoriana de Arbitraje, No. 8, pp. 407-408.

50. E. Neira Orellana, "La Relación Procesal entre Órganos de Administración de Justicia y Tribunales de Arbitraje", Revista Ecuatoriana de Arbitraje", No. 4, 2012, pp. 52-53. Ver, Corte Constitucional del Ecuador, Caso No. 323-13-EP, N. 2: "El texto constitucional, en su artículo 190, reconoce al arbitraje alternativo para la solución de conflictos, cuestión que además de hacer este mecanismo mediante un respaldo a la autonomía de las personas, implica un pleno reconocimiento de un sistema 'alternativo' con normas y procedimientos propios". 
arbitral frente a intervenciones de la justicia estatal ${ }^{51}$.

Oswaldo Santos Dávalos, es preciso al determinar a qué se refieren los principios de trascendencia y convalidación, veamos:

Trascendencia. No cualquier infracción procesal acarrea la nulidad del laudo porque el proceso no es un fin en sí mismo. Para que haya nulidad no basta 'la infracción a la norma, sino que, dicha infracción haya producido un efectivo perjuicio a los derechos del sujeto procesal interesado'. En materia de nulidad de los laudos, se ha dicho que la afectación causada por el vicio procesal debe ser sustancial.

Convalidación. Los actos procesales irregulares pueden convalidarse cuando, por ejemplo, no se ha alegado la nulidad en el tiempo oportuno. La normativa colombiana establece que ciertas causales de nulidad aplican si es que la parte afectada 'hizo valer los motivos constitutivos de ellas mediante recurso de reposición contra el auto de asunción de competencia'. Como se dijo en un fallo, 'el momento para objetar la competencia del Tribunal Arbitral; y, solicitar la nulidad de la cláusula arbitral estipulada era dentro del procedimiento arbitral'. También se ha dicho que hay ciertas alegaciones sobre la validez del proceso que deben formularse previo a la emisión del laudo: '[e]l Árbitro Único resolvió de manera motivada el pedido de nulidad de la actora, en la etapa procesal correspondiente, dejando saneado el procedimiento previo para poder continuar con el saneamiento'" ${ }^{\prime 2}$.

Consideramos que el principio de convalidación y preclusión se encuentran estrechamente ligados. En caso de que la parte que alega la nulidad del laudo arbitral no haya reclamado oportunamente al tribunal el hecho o acto sobre el cual pretende anular el laudo, se ve impedida de hacerlo, pues el momento adecuado ya feneció.

La incorporación de todos estos principios a través de una norma expresa son una guía tanto para el juez sustanciador de la causa, como para las partes que pretenden anular el laudo; nos explicamos. Las partes intervinientes en un arbitraje, conscientes de la alternabilidad de este mecanismo, debe respetar su curso

51. M. E. JARA, "Decisiones de la justicia estatal ecuatoriana sobre arbitraje. Un análisis desde la perspectiva del principio favor arbitralis", Universidad Andina Simón Bolívar, 2013, pp. 6-7.

52. Ver, O. Santos Dávalos, N. 49, p. 408. 
y la decisión que fue tomada por el tercero dirimente en el que depositaron su confianza. Sin perjuicio de que existen casos en los que amerita una nulidad de laudo, otras ocasiones, se busca relitigar el proceso a través de maniobras jurídicas para no ser condenados porque la decisión no es de su agrado.

Si tomamos como referencia un estudio realizado en años pasados por Oswaldo Santos Dávalos, donde el número de procesos analizados fue 61, queda comprobado que el porcentaje de acciones de nulidad que prosperan es del $11,48 \%$, mientras que el $88,52 \%$ no son aceptadas ${ }^{53}-54$ de 61-. Este resultado llama la atención, pues consideramos que el que no se haya declarado la nulidad está estrictamente ligado a la falta de bases sólidas y argumentos en derecho.

Por este motivo, se hace hincapié en que la nulidad no será declarada si: (i) la parte que interpone la nulidad no ha reclamado el origen de la nulidad durante el proceso arbitral oportunamente; (ii) pese a existir una causal, no se ha generado un perjuicio cierto o irreparable; (iii) la causal pudo ser subsanada durante el proceso arbitral y, esto no ocurrió por inactividad del accionante.

La inclusión expresa de la anulación parcial de un laudo en caso de que la causal se circunscriba solo a ciertos pronunciamientos afectados, es, sin lugar a dudas, un elemento que busca proteger la eficacia del sistema arbitral y la sanción de nulidad como un remedio de última instancia. Esta norma del Reglamento además refleja las decisiones de las cortes de anulación en la materia. Por ejemplo, el Presidente de la Corte Provincial de Pichincha en un caso donde se alegó la causal de extra petita, anuló únicamente la parte del laudo que comprendía dicha causal y dejó en firme las partes del laudo no afectadas:

53. Ver, O. Santos Dávalos, N. 49, p. 415: "Decimos que no fue aceptada y no que fue rechazada porque hubo casos en que se declaró el abandono o las partes llegaron a un acuerdo que puso fin al proceso de nulidad. Además, se debe tomar en consideración que hubo casos en que el tribunal no se pronunció sobre el fondo de la alegación de nulidad. Una razón frecuente para que los jueces dictaran sentencias non liquet fue que la acción había sido dirigida exclusivamente en contra de los árbitros a quienes, tal como explicamos, nuestra jurisprudencia no considera legítimos contradictores. Hubo también casos en que la acción fue rechazada porque se estimó que el actor no satisfizo la carga de probar la causal de nulidad invocada". 
Se acepta la acción de nulidad propuesta en contra del laudo arbitral de 23 de octubre de 2017 a las 15h00, en el juicio arbitral No. 075-10 seguido por la compañía Pinturas Wesco S.A. [...] en contra del Banco de Guayaquil S.A. [...], en consecuencia se declara la nulidad parcial, en lo referente, a la indemnización de perjuicios del período comprendido en los años 2012 al $2016^{54}$.

Finalmente, pero no menos importante, basado en el principio de in dubio pro arbitri y conservación, el Reglamento establece que en caso de duda sobre la causal invocada, se preferirá mantener la validez del laudo arbitral.

\subsection{Tramitación de la acción de nulidad por las Cortes Provinciales}

El artículo 13 del Reglamento prescribe en su segundo numeral que:

2. Una vez presentada la acción de nulidad y previo al envío del expediente a la Corte Provincial, el tribunal arbitral mantendrá una copia certificada, digital o física, del expediente bajo responsabilidad del actuario que recibe. Para la recepción del expediente en la Presidencia de la Corte Provincial no se exigirá que esté numerado o foliado o que cumpla con requisito adicional alguno.

3. Desde la fecha de recepción del expediente, el Presidente de la Corte Provincial, en el término de 5 días, avocará conocimiento de la causa, calificará la acción y otorgará el término de 10 días para su contestación. Este auto se notificará a las partes en el último domicilio señalado por estas en el arbitraje y en cualquier domicilio adicional que haya sido identificado en la solicitud de anulación del laudo.

4. El Presidente de la Corte Provincial deberá resolver la acción de nulidad dentro del término de 30 días desde que avocó conocimiento, para lo cual convocará a una audiencia en la que escuchará los alegatos de las partes. Si la complejidad de la causa lo amerita, de manera excepcional el juez podrá suspender la audiencia y reanudarla en el término máximo

54. Presidencia de la Corte Provincial de Pichincha, Proceso No. 17100-2018-00026, 01/02/2019. 
de 10 días. Durante este término, previa autorización del Presidente, las partes podrán presentar escritos adicionales con el fin de ayudar a la mejor resolución del caso.

5. Las entidades del sector público no se encuentran obligadas a presentar la acción de nulidad con el fin de agotar las instancias de impugnación, sino únicamente cuando, conforme a las disposiciones de la Ley de Arbitraje y Mediación y de este Reglamento, existan fundamentos claros de la existencia de una causal de nulidad que pueda afectar la validez del laudo.

6. El abuso de derecho en el ejercicio de la acción de nulidad será sancionado conforme lo dispuesto en la legislación ecuatoriana.

Es importante comenzar enunciando que si bien el artículo 31 de la LAM prevé ciertos pasos a seguir para la sustanciación de la acción de nulidad, no desarrolla un procedimiento específico y dejó por mucho tiempo, la puerta abierta a varias interpretaciones. Por ejemplo, si debía tramitarse como un procedimiento especial u ordinario, si cabía o no la apelación de la sentencia de nulidad de primera instancia o si se podía interponer recurso de casación o no, etc. ${ }^{55}$

Ahora bien, de manera sucinta, el trámite a seguir conforme el la LAM y el Reglamento, es el siguiente: (i) se debe presentar la acción de nulidad ante el tribunal arbitral dentro de los diez días término siguientes a la ejecutoría del laudo ${ }^{56}$. En caso de que una parte solicite la suspensión de los efectos del laudo se procederá conforme los últimos tres incisos del artículo 31 de la LAM; (ii) el tribunal arbitral remitirá al Presidente de la Corte Provincial el expediente arbitral; (iii) el Presidente de la Corte Provincial avocará conocimiento dentro del término de cinco días luego de recibido el expediente arbitral; (iv) el Presidente deberá calificar la acción y verificar si fue interpuesta dentro

55. Ver, V. Chiriboga Arteta, La problemática actual de la acción de nulidad en contra de los laudos arbitrales, Tesina de grado para la obtención del título de abogada, 2012, pp. 53-56.

56. Sobre la ejecutoría del laudo arbitral, y cómo deben proceder los tribunales arbitrales y Cortes Provinciales cuando una acción fue interpuesta dentro del término previsto en la Ley. Ver, (i) Corte Constitucional del Ecuador, Caso No. 1037-10-EP, Sentencia No. 155-12-SEP-CC, 17/04/2012; y, (ii) Corte Constitucional del Ecuador, Caso No. 308-14-EP, Sentencia No. 30814-EP/20, 19/08/2020. 
del término antes mencionado; (v) De confirmarse, se otorgará al accionado para contestar la demanda el término de diez días; (vi) se convocará a la audiencia única en el término máximo de treinta días contados desde que avocó conocimiento de la causa, audiencia que se puede suspender con el fin de otorgarle al juez un tiempo prudente para tomar una decisión, y, que en ese término, las partes presenten escritos adicionales.

Adicionalmente, el Reglamento incorpora dos disposiciones importantes: (i) la primera busca frenar la mala práctica de las instituciones públicas que, a guisa de una cura preventiva ante la Contraloría General del Estado, creen estar obligadas a impugnar toda decisión, inclusive si la impugnación contraviene la más elemental lógica; (ii) la segunda elimina la práctica arcaica de exigir que el expediente del arbitraje sea foliado para su entrega a la Corte Provincial respectiva.

Finalmente, este artículo merece un comentario final y es su relación con la Resolución No. 08-2017 expedida por la Corte Nacional de Justicia. Si bien ambas disposiciones son, en esencia, compatibles, existe una diferencia clara: el Reglamento otorga 10 días para contestar la acción de nulidad; la resolución solo 5. En este sentido, por especificidad, garantismo y jerarquía normativa, consideramos que el Reglamento prevalece sobre la resolución. Pero sin lugar a dudas esta particular incompatibilidad debe ser resuelta en aras de la claridad y seguridad en la materia.

\section{LA EJECUCIÓN DE LAUdOS ARBITRALES INTERNACIONALES}

Con la expedición de la Ley de Fomento Productivo se revivió al actual último inciso del artículo 42 de la LAM -que fue derogado con la expedición del COGEP- que dispone que los laudos internacionales serían ejecutados de la misma manera que los laudos nacionales. El Reglamento se ocupa de evitar cualquier interpretación que no favorezca un trámite ágil y menos gravoso para el acreedor. Si bien existía un consenso generalizado sobre que, bajo el imperio del artículo 42 original de la LAM, no era necesario un procedimiento de homologación, cuando se expidió el COGEP se incorporó dicho procedimiento previo a cualquier ejecución de laudo internacional. Como se 
mencionó, la Ley de Fomento Productivo regresó al sistema original eliminando las referencias a laudo arbitral de los artículos 102 y 106 del COGEP, el legislador omitió derogar la misma referencia en el numeral quinto del artículo 363 del COGEP donde se reconoce su naturaleza de título de ejecución a los laudos arbitrales. Esto generó, por decir lo menos, confusión en los operadores de justicia ordinaria e inseguridad jurídica. Es clara que la intención del legislador fue la eliminación del proceso de homologación de laudos arbitrales internacionales, más allá de la desprolija técnica legislativa. En este sentido, el artículo 15 del Reglamento cobra suma relevancia al disponer que: (i) los laudos internacionales se ejecutarán de la misma manera que los laudos nacionales, sin que se requerirá homologación; (ii) no será necesaria la razón de ejecutoría, legalización o formalidad del laudo; (iii) el ejecutado podrá oponerse a la ejecución del laudo solo cuando compruebe el cumplimiento de la obligación, la suspensión o declaratoria de nulidad por autoridad competente; (iv) no se puede entorpecer el proceso a través de la aceptación de recursos infundados.

\section{Regulación de la JUSTiCia CAUTELAR}

Un tema pacífico bajo la legislación ecuatoriana es que los árbitros tienen la facultad de otorgar medidas cautelares durante la sustanciación del procedimiento arbitral. Así lo prevé la LAM expresamente. Así también, es claro que los árbitros podrán ejecutar las medidas que dicten con auxilio del aparataje estatal, si así lo convinieron; caso contrario, serán los jueces ordinarios quienes lo harán. El artículo 9 de la LAM también prevé que los árbitros podrán dictar las medidas "que consideren necesarias para cada caso", estableciendo sin discusión que son procedentes tanto las medidas contempladas en la normativa procesal supletoria, como aquellas que se conocen como "innominadas":

Art. 9.- Los árbitros podrán dictar medidas cautelares, de acuerdo con las normas del Código de Procedimiento Civil o las que se consideren necesarias para cada caso, para asegurar los bienes materia del proceso o para garantizar el resultado de éste. Los árbitros pueden exigir una garantía a quien solicite la medida, con el propósito de cubrir el pago 
del costo de tal medida y de la indemnización por daños y perjuicios a la parte contraria, si la pretensión fuera declarada infundada en el laudo.

La parte contra quien se dicte la medida cautelar podrá pedir la suspensión de esta, si rinde caución suficiente ante el tribunal.

Para la ejecución de las medidas cautelares, los árbitros siempre que las partes así lo estipularen en el convenio arbitral, solicitarán el auxilio de los funcionarios públicos, judiciales, policiales y administrativos que sean necesarios sin tener que recurrir a juez ordinario alguno del lugar donde se encuentren los bienes o donde sea necesario adoptar las medidas.

Si nada se estableciere en el convenio arbitral acerca de la ejecución de las medidas cautelares, cualquiera de las partes podrá solicitar a los jueces ordinarios que ordenen la ejecución de estas medidas, sujetándose a lo establecido en el párrafo dos (2) y tres (3) de este artículo, sin que esto signifique renuncia al convenio arbitral.

Sin embargo, ante la silente postura del legislador respecto a las medidas cautelares previo a que se constituya el tribunal arbitral, y la falta de previsión de la conocida figura del 'árbitro de emergencia' en los reglamentos de los Centros, en la práctica se ha optado por acudir a la jurisdicción ordinaria y la figura de medidas preventivas recogidas en el COGEP. El Reglamento llega para aclarar dos panoramas que son de vital importancia en el Ecuador: [§ 6.1] el arbitraje de emergencia [§ 6.2] la potestad de los jueces para otorgar cualquier medida cautelar que el caso demande para mantener el status quo.

\subsection{Reconocimiento de la figura del árbitro de emergencia}

La finalidad de las medidas cautelares es "[e]vitar que el justiciable vea sus derechos evaporados al final del proceso, la ley contempla distintos medios que le permiten, al menos provisoriamente, disminuir los riesgos, los que comúnmente toman el nombre de medidas cautelares, medidas provisionales o medidas 
precautorias" ${ }^{57}$. En este sentido, no son pocos los casos en los que se busque precautelar derechos, las pruebas que demostrarán los hechos alegados, los bienes con los que presuntivamente deberá responder la parte vencida, entre otros.

Frente a esta necesidad nace la figura del árbitro de emergencia cuya finalidad no es solo precautelar los derechos de una parte, sino maximizar la eficacia del laudo y el arbitraje per se. Los beneficios que conlleva esta institución son varios, por ejemplo: (i) garantiza el sistema autocontenido; (ii) evita la intervención judicial; (iii) impide el contagio de ritualismos y formalismos; (iv) proporciona la confidencialidad que las partes buscaban al pactar arbitraje; y, más importante (v) asegura la eficiencia y agilidad propio del arbitraje. En resumen, "el arbitraje de emergencia se convierte en un mecanismo ideal para que las partes no tengan que abstraerse del sistema arbitral cuando requieran la obtención de una medida cautelar urgente antes de que un tribunal arbitral se haya constituido" ${ }^{58}$.

La LAM no prevé expresamente esta figura. No obstante, su aplicación en Ecuador ya era procedente por un simple motivo: el arbitraje se construye sobre la base de la autonomía de la voluntad de las partes. Esto significa que si se acordaba arbitraje de emergencia en el convenio arbitral para solicitar medidas cautelares, o se sometían a un centro cuyo reglamento lo contempla, las partes están facultadas a solicitarlas. En este sentido, la disposición del Reglamento llama una vez más a los Centros a modernizar sus normas internas para adaptarse a la necesidad de las partes, al mercado global ${ }^{59}$.

En este sentido, los Centros, por ejemplo, deberán regular: (i) el ámbito de aplicación del arbitraje de emergencia -temporal y personal-; (ii) el procedimiento a seguir por la parte solicitante y

57. R. Bordachar URRUTIA, "Medidas cautelares en arbitraje y la incorporación del árbitro de emergencia", Derecho y Ciencias Sociales, Vol. XIII, 2015, p. 74.

58. E. Cargmigniani, H. García, "Arbitraje de emergencia: propuesta del CEA", Revista del Club Español del Arbitraje, Número Especial, 2020.

59. Centro Internacional para la Resolución de Disputas (ICDR), 2006; Instituto Internacional para la Prevención y Resolución de Conflictos (CPR), 2019; Instituto de Arbitraje de la Cámara de Comercio de Estocolmo, 2020 (SCC); Centro de arbitraje internacional de Singapur (SIAC), 2016; Centro Australiano de Arbitraje Comercial Internacional (ACICA), 2021; Cámara de Comercio Internacional (ICC), 2021, Corte de Arbitraje Internacional de Londres (LCIA), 2020; Centro de Arbitraje Internacional de Hong Kong (HKIAC), 2018. 
los términos para garantizar el trámite expedito; (iii) el objeto de las medidas preventivas -independientemente de las que ya reconoce expresamente el Reglamento-; (iv) los requisitos de admisibilidad de la solicitud-que son al menos exigidos parar otorgar una medida cautelar ordinaria ${ }^{60}$.

Respecto a las medidas que pueden dictar los árbitros de emergencia, mutatis mutandis, resulta lógico, que serán las mismas que las de un tribunal arbitral durante la sustanciación de un procedimiento arbitral regular -innominadas y/o taxativas contempladas en el COGEP-. No obstante, y en aras de evitar discrecionalidad alguna, el Reglamento lo contempla expresamente:

1. El tribunal arbitral o los árbitros de emergencia que estén previstos en los reglamentos de los Centros de Arbitraje y Mediación, podrán dictar cualquier medida cautelar que consideren necesaria para cada caso, con el fin de:

a. Mantener o reestablecer el status quo en espera de que se dirima la controversia.

b. Impedir la continuación de algún daño actual, o la materialización de un daño inminente o el menoscabo del procedimiento arbitral.

c. Preservar bienes que son materia del proceso o, en general, los bienes del deudor o del acreedor.

d. Preservar elementos de prueba que puedan ser relevantes para resolver la controversia.

e. Garantizar el cumplimiento de las obligaciones materia del arbitraje.

f. Preservar la competencia de un tribunal arbitral.

60. Ver, Código Orgánico General de Procesos, Artículo 125, RO No. 506, 22/05/2015. 
Lo dispuesto en la noma citada, guarda concordancia y armonía con lo reconocido en la doctrina ${ }^{61}$, la ley especial de la materia ${ }^{62}$, Ley Modelo CNUDMI ${ }^{63}$ y reglamentos internacionales ${ }^{64}$.

Finalmente, consideramos oportuno mencionar que bajo la legislación ecuatoriana, no existe una problemática práctica respecto a la forma que toma la medida cautelar otorgada por el árbitro de emergencia para tramitar su ejecución -en caso de que no se haya otorgado esta facultad al árbitro de emergencia-. El artículo 363 del COGEP manda expresamente que "Las y los juzgadores [...] ejecutarán las providencias preventivas ordenadas por los tribunales de arbitraje nacionales o internacionales" ${ }^{\prime \prime 5}$.

Por lo expuesto, sin duda el Reglamento constituye el empuje que el arbitraje necesitaba para que el uso del arbitraje de emergencia se fomente en el país a través de pautas claras como guía.

\subsection{Medidas preventivas y la justicia ordinaria}

Como se mencionó previamente, la solución práctica por la que se decantó el foro ecuatoriano para solicitar medidas cautelares previo a que se constituya el tribunal arbitral fue acudir a la jurisdicción ordinaria. A raíz de esta práctica se formularon dos posturas referentes a qué tipo de medidas pueden otorgar los jueces. Un sector optó por defender que los jueces podrían otorgar cualquier

61. Ver, E. Salcedo Verduga, Las medidas cautelares en el arbitraje, Corporación de Estudios y Publicaciones CE, 2006.

62. Ley de Arbitraje y Mediación, N. 3, Artículo 9.

63. Ley Modelo CNUDMI sobre Arbitraje Comercial internacional de 1985 con las enmiendas aprobadas en 2006 (2008), N. 12, Artículo 17(2): "Por medida cautelar se entenderá toda medida temporal [...] [que] el tribunal arbitral ordene a una de las partes que: a) mantenga o restablezca el status quo en espera de que se dirima la controversia; b) adopte medidas para impedir algún daño actual o inminente o el menoscabo del procedimiento arbitral, o que se abstenga de llevar a cabo ciertos actos que probablemente ocasionarían dicho daño o menoscabo al procedimiento arbitral; c) proporcione algún medio para preservar bienes que permitan ejecutar todo laudo subsiguiente; o d) preserve elementos de prueba que pudieran ser relevantes y pertinentes para resolver la controversia".

64. Ver, No. 59.

65. Código Orgánico General de Procesos, No. 60, Artículo 363(2). Claro está, que en el caso de arbitrajes internacionales, no existirá la necesidad de homologar la decisión, laudo, orden que contenga la medida preventiva, pues como ya se demostró este requisito ha sido eliminado en nuestra legislación para decisiones de esta naturaleza. 
medida que consideren óptima ${ }^{66}$. Otro grupo -aunque minoritarioargüía que las medidas procedentes eran taxativas ${ }^{67}$.

La primera tesis se fundamenta en el texto expreso de la LAM. El artículo 9 de la LAM prescribe que "si nada se estableciere en el convenio arbitral acerca de la ejecución de las medidas cautelares, cualquiera de las partes podrá solicitar a los jueces ordinarios que ordenen la ejecución de estas medidas [...]"68. Así de simple. El artículo 9 de la LAM autoriza expresamente a los jueces ordinarios a dictar medidas cautelares en auxilio a un arbitraje. Y eso no tiene novedad. En todo sistema arbitral son los jueces ordinarios de lo civil los órganos auxiliares de arbitraje. Esto solo estaría limitado por una renuncia expresa de las partes en el convenio arbitral ${ }^{69}$. La doctrina es unánime sobre este punto. Solo como ejemplo, Alejandro Ponce Martínez manifiesta que "los jueces tienen la facultad de ordenar medidas cautelares, antes de que se inicie el proceso de arbitraje e inclusive antes de que se constituya el tribunal arbitral[...]"70.

Ahora, sobre qué tipo de medidas pueden dictar los jueces ordinarios, el artículo 9 de la LAM también es claro. La expresión "estas medidas" del último párrafo no puede entenderse en el artículo 9 de la LAM sin la referencia a las medidas que pueden ordenar los árbitros. Así, cuando el primer párrafo dice que los árbitros pueden ordenar las medidas "que se consideren necesarias para cada caso", y el último párrafo dice que los jueces ordinarios pueden ordenar "la ejecución de estas medidas", no puede sino entenderse que el uso de la palabra "estas" es para referirse a

66. Ver, (i) Unidad Judicial de lo Civil con sede en el cantón Guayaquil, Proceso No. 09332-201800849G, 23/08/2018; (ii) Unidad Judicial de lo Civil con sede en el cantón Guayaquil, Proceso No. 09332-2018-00850G, 24/08/2018; (iii) Sala Especializada de lo Civil y Mercantil de la Corte Provincial de Justicia de Guayas, Proceso No. 09332-2018-00850G, 29/01/2019; (iv) Sala Especializada de lo Civil y Mercantil de la Corte Nacional de Justicia, Proceso No. 093322018-00850G, 31/05/2019; (v) Unidad Judicial de lo Civil con sede en el cantón Guayaquil, Proceso No. 09332-2020-00179G, 30/11/2020; (vi) Sala Especializada de lo Civil y Mercantil de la Corte Provincial de Justicia de Guayas, Proceso No. 09332-2020-00179G, 01/06/2021; (vii) Unidad Judicial de lo Civil con sede en la parroquia de Iñaquito, Proceso No. 17230-202100085G, 01/04/2021; y, (viii) Sala Especializada de lo Civil y Mercantil de la Corte Provincial de Justicia de Pichincha, Proceso No. 17230-2021-00085G, 30/07/2021.

67. Ver, Sala Especializada de lo Civil y Mercantil de la Corte Provincial de Justicia de Guayas, Proceso No. 09332-2018-00849G, 04/01/2019.

68. Ley de Arbitraje y Mediación, No. 3, Artículo 9. Énfasis añadido.

69. De ahí la expresión "si nada se estableciere en el convenio arbitral acerca de la ejecución de las medidas cautelares” del Artículo 9 de la Ley de Arbitraje y Mediación, No. 3.

70. A. Ponce Martínez, "Ejecución de medidas provisionales: interacción entre árbitros y jueces", Boletín Arbitral Amcham Quito, No. 4, 28/09/2012, p. 4. 
aquellas "que se consideren necesarias para cada caso". La doctrina también ha sido clara al respecto. Nuevamente, por ejemplo, Alejandro Ponce Martínez, concluye que:

Los jueces tienen la facultad de ordenar medidas cautelares, antes de que se inicie el proceso de arbitraje e inclusive antes de que se constituya el tribunal de arbitral, una vez planteada la demanda y contestada esta. En virtud de la existencia de cláusula arbitral, debe entenderse que tales jueces no solo están autorizados para ordenar las medidas provisionales previstas en el Código de Procedimiento Civil (secuestro, retención, prohibición de enajenar bienes raíces y prohibición de ausentarse del país para extranjeros que carezcan de bienes raíces en el Ecuador) y las previstas en leyes especiales [...] sino aquellas que pueden ser necesarias para el cumplimiento del arbitraje por iniciarse, como la de mantener el status quo o la de preservar las pruebas o las que permitan garantizar los resultados del proceso $^{71}$.

En el mismo sentido, el profesor Salcedo Verduga establece que:

La citada disposición encuentra su ratio legis en que el legislador no puede prever todas las situaciones de las cuales pueda resultar viable, en el proceso arbitral, la adopción de una medida cautelar específica, de modo que resulta útil contar con una norma que en forma flexible asegure esa posibilidad. Por esta razón, los órganos jurisdiccionales de arbitraje tienen en el Ecuador -al amparo del art. 9 de la LAM- poderes suficientes para ordenar, a pedido de parte y de acuerdo con las circunstancias, la medida cautelar más idónea que estimen necesaria para asegurar el derecho invocado ${ }^{72}$.

La segunda y rígida postura -que ha encontrado eco en una sola decisión- halla fundamento en una interpretación restrictiva del COGEP que contempla como medidas preventivas solamente a: (i) prohibición de enajenar73; (ii) secuestro ${ }^{74}$; (iii)

71. Ídem.

72. E. Salcedo Verduga, N. 61, p. 73.

73. Ver, Código Orgánico General de Procesos, N. 60, Artículo 126.

74. Ídem, Artículo 129. 
retención ${ }^{75} ; \mathrm{y}$, (iv) arraigo ${ }^{76}$, conforme el artículo 124 que reza "cualquier persona puede, antes de presentar su demanda y dentro del proceso, solicitar el secuestro o la retención de la cosa sobre la que se litiga o se va a litigar o de los bienes que aseguren el crédito" 77 . Producto de ambos criterios, existen fallos contradictorios que ocasionaron inseguridad, como veremos a continuación.

El artículo 8 del Reglamento solo reafirma las constantes y mayoritarias decisiones de las cortes ecuatorianas ecuatoriana que permiten a los jueces ordinarios dictar medidas cautelares innominadas previo a la constitución del tribunal arbitral:

2. Antes de que esté constituido el tribunal arbitral, la parte interesada podrá solicitar la adopción de las medidas cautelares contempladas en el Código General de Procesos o cualquier otra medida cautelar que considere necesaria de las previstas en el numeral 1 de este artículo. Esta solicitud será presentada a los jueces de lo civil que habrían tenido competencia para resolver la disputa de no haber convenio arbitral, sin que esto se considere como una renuncia al mismo. La solicitud seguirá el mismo procedimiento que el Código General de Procesos prevé para tramitar la solicitud de providencias preventivas.

Finalmente, creemos importante referirnos a un último tema brevemente. El Reglamento prevé en su artículo 9 el procedimiento de modificación, suspensión o revocación de las medidas cautelares otorgadas previamente o durante la sustanciación del procedimiento arbitral, por un juez, árbitro de emergencia, o tribunal arbitral ${ }^{78}$. Sin duda todas las guías trazadas en las normas citadas en esta sección permitirán que el arbitraje se practique más sofisticadamente y traerá consigo beneficios.

75. Ídem, Artículo 130.

76. Ídem, Artículo 131.

77. Ídem, Artículo 124.

78. Reglamento a la Ley de Arbitraje y Mediación, N. 15, Artículo 9: “1. Las partes podrán pactar y determinar libremente las reglas procesales a las que se sujetará el tribunal arbitral en sus actuaciones, sea directamente o por referencia a un reglamento arbitral. A falta de acuerdo o en ausencia de una disposición aplicable, el tribunal arbitral decidirá las reglas que considere más apropiadas teniendo en cuenta las circunstancias del caso pudiendo para esto recurrir a los principios y prácticas de uso común en materia arbitral. 2. Supletoriamente, cuando no contravenga los principios del arbitraje y si el tribunal estimare oportuno, se podrán aplicar las disposiciones contenidas en el Código Orgánico General de Procesos". 


\section{Temas misceláneos}

En esta sección abordaremos temas varios incluidos en el Reglamento que consideramos, no deben dejar de ser comentados ya que fomentan y consolidan el arbitraje. Veremos a continuación el tratamiento que le da el Reglamento a [\$ 7.1] la confidencialidad y su alcance; [§ 7.2] la responsabilidad de los árbitros; [§ 7.3] la competencia de los árbitros y el plazo para dictar el laudo; [\$ 7.4] la regulación del arbitraje internacional; y, [§ 7.5] la extensión del convenio arbitral.

\subsection{La confidencialidad del arbitraje y su alcance}

No es desconocido que uno de los beneficios inherente del arbitraje es la confidencialidad. Ya sea que porque las partes así lo pacten expresamente o porque la lex arbitri lo contemple como regla general, esta característica resulta un factor decisivo al momento de acordar la justicia arbitral porque:

Protege la reputación de las partes frente a terceros, convirtiéndose en una de las razones que motivan a muchos inversionistas y comerciantes para acudir al proceso arbitral. Resulta lógico que estos prefieran acudir a arbitraje, pues la confidencialidad garantizaría que aquellos no involucrados en el conflicto desconozcan su existencia y así no se vea afectado su posicionamiento en el mercado por las distintas disputas a las que se enfrentan ${ }^{79}$.

El artículo 34 de la LAM manda que "las partes sin perjuicio de los derechos de terceros, podrán convenir en la confidencialidad del procedimiento arbitral, en este caso podrán entregarse copias de lo actuado solamente a las partes, sus abogados o al juez que conozca el recurso de nulidad". Vale la pena hacer un análisis de este texto.

En la primera parte del artículo encontramos una limitación a la confidencialidad: los "derechos de terceros" -frase que resulta un tanto indefinida ${ }^{80}$-. Otras limitaciones son: "(i) el consentimiento

79. C. CEPEDA, "El arbitraje y la importancia del principio de confidencialidad", USFQ Law Review, No. 1, 2013, p. 4.

80. Ídem, p. 7: "Por otra parte, nuestro sistema impone una limitación a este principio: la posible afectación a derechos de terceros, lo cual resulta confuso. El sistema arbitral, al ser de naturaleza 
de las partes de no confidencialidad, (ii) por orden judicial; (iii) por permiso del tribunal; (iv) por una necesidad razonable para defender los intereses de las partes" ${ }^{\prime 81}$; (v) que se ventile el proceso arbitral en cualquier instancia de la justicia ordinaria o constitucional -nulidad, ejecución, medidas cautelares, Acción Extraordinaria de Protección, etc.-; (vi) la existencia de una norma que disponga la no confidencialidad en casos específicos.

Adicionalmente, y distinto a lo que ocurre en otros países, por ejemplo en Perú, en caso de que las partes no pacten confidencialidad se entiende que el procedimiento es público. No obstante, en la segunda parte del artículo podemos identificar que una vez convenida la confidencialidad, existe una restricción de acceso a las actuaciones a las partes, sus abogados, y al 'juez que conozca el recurso de nulidad'.

Lo cierto es que en torno a la confidencialidad se han generado discusiones y posiciones divergentes respecto a su alcance objetivo y subjetivo, si es posible y prudente la publicación de laudos arbitrales, la naturaleza y origen de la obligación de confidencialidad de los distintos agentes, las medidas que pueden tomarse en caso de una falta a este principio, cómo proceder en caso de corrupción, etc. ${ }^{82}$. Además, no tenemos en nuestro conocimiento casos -ya sean civiles o arbitrales- que se hayan iniciado y hayan prosperado. Lo más cercano son dos casos relacionados y sustanciados ante el Centro de

privada, nace de un convenio de particulares aceptado por la ley. El convenio arbitral únicamente es oponible a aquellos que forman parte de él. Esto quiere decir que no podría afectar a terceros en virtud del principio de relatividad de los negocios jurídicos, el cual determina que 'los actos jurídicos no perjudican ni aprovechan a terceros'. Es por ello que, en el supuesto de que los efectos que se generen del proceso arbitral llegaren a afectar a terceros, como lo determina el artículo expuesto, estos dejarían de ser ajenos al arbitraje. Se convertirían en plenos sujetos procesales por lo que la confidencialidad no se tomaría en cuenta respecto de ellos. No obstante, se pondría en duda la validez del proceso arbitral en relación a estos supuestos terceros, ya que ellos no se han sometido voluntariamente a este sistema".

81. Ídem, p. 5; I. M. Smeureanu, Confidentiality in International Commercial Arbitration, Kluwer Law International: Great Britain, 2011. p. 44.

82. Ver, C. CEPEDA, No. 79. Ver además, sobre la responsabilidad de los centros de arbitraje y mediación, y los árbitros: (i) N. OrdóñEz RIVERA, "Responsabilidad de los Centros de Arbitraje en Ecuador", Revista Ecuatoriana de Arbitraje, No. 9, 2017; y, (ii) D. MOLINA COELLO, "Menos sorpresas e incertidumbre: propuesta de reforma a la Ley de Arbitraje y Mediación (LAM) en materia de responsabilidad civil de los árbitros, los centros de arbitraje y sus directores", Revista Ecuatoriana de Arbitraje, No. 11, 2020. Sobre los límites a la confidencialidad ante corrupción, J. F. GoNZÁLEZ, “¿Qué hacer cuando la corrupción llega al arbitraje? Una perspectiva ecuatoriana sobre el rol del árbitro y de las partes procesales", Revista Ecuatoriana de Arbitraje, No. 9, 2017. 
Arbitraje y Conciliación de la Cámara de Comercio de Guayaquil aunque en ambos se desecharon las demandas ${ }^{83-84}$.

A nuestro criterio, la confidencialidad es una ventaja que alcanza a (i) la disputa; (ii) los documentos y pruebas ventilados en el proceso; y, (iii) al laudo arbitral. Solo así, se cumple el fin último de proteger a las partes. Creemos además, que es posible -y necesarioencontrar un equilibro entre la confidencialidad y tendencias internacionales de publicar las decisiones de tribunales arbitrales con fines académicos. Esto permite inclusive, que se promueva la transparencia, se alimente la confianza en el sistema arbitral a través de publicidad e, inclusive, que se genere un incentivo reputacional para los árbitros de producir decisiones de calidad.

No obstante, si las partes han pactado confidencialidad, esta puede verse vencida por la publicidad de los procesos relacionados al arbitraje que eventualmente se ventilan en justicia ordinaria. Es claro que para preservar esta confidencialidad era necesario dar, particularmente al juez de nulidad, las herramientas para poder permitir que dicho principio se garantice. Así el artículo 11(2) incorpora una norma necesaria que permite a los jueces dictar "cualquier medida necesaria para preservar la confidencialidad de información sensible, incluyendo la restricción de acceso al expediente únicamente a las partes mientras se tramita la acción de nulidad, la no identificación de las partes o el calificar cualquier

83. Procesos Arbitrales Centro de Arbitraje y Conciliación de la Cámara de Comercio de Guayaquil No. 044-2013, 13/11/2014 y No. 045-2013, 27/09/2014.

84. En el Proceso Arbitral Centro de Arbitraje y Conciliación de la Cámara de Comercio de Guayaquil No 045-2013, 27/09/2014, el tribunal hizo la siguiente consideración: "sin exposición pública, no existe violación a la confidencialidad del arbitraje. [...] Lo anterior es un ejemplo claro de que la confidencialidad no es absoluta, y además, que la información que recibimos los árbitros no trasciende al público manteniendo la confidencialidad acordada por las partes, como ocurrió [...]. Como se lo expresó en el considerando anterior, por ser el arbitraje una institución relativamente nueva en el sistema normativo ecuatoriano no existe jurisprudencia sobre el alcance de los pactos de confidencialidad que las partes acuerden para el mismo, lo que da lugar a confusión respecto a la confidencialidad, que a nuestro juicio no es absoluta; tanto es así, que el articula 34 de la Lev de Arbitraje y Mediación refiere que el acuerdo de confidencialidad consiste en que solamente se pueden entregar copias de lo actuado a las partes, sus abogados o al juez que conozca el recurso de nulidad; es decir, la prohibición absoluta es que se entregue copias de lo actuado a terceros [...]. Dicho de otra manera, el arbitraje no es por si confidencial, lo que pueden las partes es incluir una cláusula de confidencialidad, pues no aceptamos que todo convenio arbitral lleve implícita confidencialidad, y ello se desprende del antes invocado artículo 34 de la ley de la materia, que deja a la voluntad de las partes convenir en una confidencialidad limitada". 
información o razonamiento que conste en la decisión que se mantendrá en el archivo público de la judicatura".

\subsection{La responsabilidad de los árbitros}

El artículo 18 de la LAM prevé que una vez que los árbitros acepten su encargo, se encuentran obligados a cumplir las funciones que la ley asigna, debiendo responder en caso de "incumplimiento de sus funciones por los daños y perjuicios que su acción u omisión les causare". Desde la academia ya se decía que si bien la LAM aborda la responsabilidad civil de los árbitros, no quedaba clara si su fuente es contractual o extracontractual. Los fundamentos para cada una de ellas se resumen en lo siguiente:

La tesis que apoya la imputación de responsabilidad civil contractual afirma que los árbitros no pueden ser asemejados a los jueces ordinarios; mientras que la que apoya a la responsabilidad extracontractual aboga por su semejanza ${ }^{85}$.

El sector que se inclina por la primera tesis, sustenta su posición en que:

No existe en la actualidad duda de que los procedimientos arbitrales son procedimientos jurisdiccionales incluso constitucionalmente reconocidos, lo cual a su vez se traduce en que las actuaciones que el árbitro o árbitros realizan dentro del procedimiento, son actuaciones de índole jurisdiccional ${ }^{86}$.

Mientras, quienes se inclinan por la segunda posición, defienden que los árbitros cumplen obligaciones derivadas del contrato de receptum arbitri celebrado entre las partes y los árbitros ya sea expresa o tácitamente. En palabras de Javier Jaramillo Troya, esto se debe a que:

[La] deficiente prestación de servicios profesionales implica, necesariamente, la consideración de un vínculo contractual -expreso o tácito- entre cliente y profesional, [y que] parece resultar ajeno al régimen civil ecuatoriano considerar a la

85. D. Molina Coello, N. 82, p. 157.

86. J. F. Guerrero del Pozo, "¿Caben las medidas cautelares constitucionales en contra de un proceso arbitral?, Revista Ecuatoriana de Arbitraje, No. 3, 2011, p. 121. 
responsabilidad de los árbitros como extracontractual. Parece más armónico, entonces, considerar a la responsabilidad arbitral como contractual bajo el contrato de receptum arbitri antes referido ${ }^{87}$.

Añade el autor sobre las obligaciones de los árbitros que, ante la falta de disposiciones expresas en la lex arbitri respecto a las conductas que generan responsabilidad contractual de los árbitros, se debe tomar como una base aquellas obligaciones que devienen del convenio arbitral, pese a ser negocios jurídicos distintos. Agrega que "las disposiciones del derecho civil común relacionadas a la responsabilidad civil contractual, también formarían parte del contrato de receptum arbitri como cláusulas naturales del negocio jurídico".

Con la expedición del Reglamento, queda claro que los árbitros podrán incurrir en responsabilidad civil con origen contractual en virtud de su consentimiento -aceptación- del receptum arbitri: el artículo 7 se dice que "la aceptación obligará a los árbitros a cumplir el encargo, incurriendo, si no lo hicieren, en responsabilidad por los daños y perjuicios que causaren por dolo o culpa grave".

Por otro lado, el artículo en mención plantea una regulación en cuanto a la gradación de la culpa -dolo o culpa grave-, que previamente no existía en nuestro sistema. Luego, se deja claro también que en caso de que esas disputas no solo son arbitrables, sino que pueden ser sometidas a arbitraje ya sea por acuerdo entre las partes y los árbitros o por referencia a un reglamento de un Centro. Esta última acotación es fundamental, ya que no son pocos los casos en los que árbitros -en especial internacionales- han declinado a sus designaciones o incluso han renunciado a sus posesiones por la oposición de una de las partes.

Finalmente, el segundo inciso del artículo en mención determina además, que las instituciones arbitrales, sus directivos y empleados en ejercicio de funciones incurrirán en la misma responsabilidad, por lo que las mismas reflexiones aplican.

87. J. JaRAmillo Troya, "La responsabilidad civil de los árbitros en el Ecuador: hacia la regulación de un ámbito no explorado”, Revista Ecuatoriana de Arbitraje, No. 8, 2016, p. 339. 


\subsection{Competencia de los árbitros y el plazo para dictar el laudo}

En el foro ecuatoriano, ya se discutía si el dictar el laudo fuera de plazo señalado en el artículo 25 de la LAM $^{88}$ tiene como efecto solo la configuración de responsabilidad de los árbitros o si esto implica además, la nulidad del laudo arbitral por incompetencia del tribunal. Respecto al primer punto, es incuestionable que el incumplimiento de los árbitros de esta obligación "genera en los árbitros la responsabilidad por daños y perjuicios. [...] ya que tras la aceptación del encargo se genera el deber en estos de resolver la controversia en el plazo fijado" 89 .

Respecto al segundo punto, ya advertimos que existen casos en los que se usó como argumento de nulidad el que se haya dictado el laudo fuera de plazo. En ciertos casos la nulidad por dictar el laudo fuera de plazo prosperó ${ }^{90} \mathrm{y}$, en otros las acciones fueron desechadas ${ }^{91}$. Es decir, que existían posiciones contrapuestas, sin embargo, esta discusión quedó zanjada con los fallos emitidos por la Corte Constitucional donde se determinó la taxatividad de las causales del artículo $31^{92}$.

El artículo 12 del Reglamento plasma coherentemente lo señalado: "la expiración del plazo para laudar no implicará la pérdida de competencia de los árbitros para expedir la resolución final, pero serán responsables ante las partes de los daños y perjuicios si dicha demora responde a negligencia grave", proporcionando así, a la comunidad arbitral una disposición expresa de la cual valerse en estos casos.

88. Ley de Arbitraje y Mediación, N. 3, Artículo 25: "Una vez practicada la audiencia de sustanciación y declarada la competencia del tribunal, este tendrá el término máximo de ciento cincuenta días para expedir el laudo. El término podrá prorrogarse, en casos estrictamente necesarios, hasta por un período igual, ya por acuerdo expreso de las partes, ya porque el tribunal lo declare de oficio".

89. J.L. GonzÁLez-Montes SÁnchez. El control judicial del arbitraje, Madrid: La Ley, 2008, p. 87.

90. Ver, Presidencia Corte Provincial de Guayas, Proceso No. 032-2009, 13/12/2011, caso en el que se subsumió el argumento en el literal e) del artículo 31 de la LAM.

91. Ver, Primera Sala de lo Civil, Mercantil, inquilinato y residuales, Proceso No. 17100-20040083, caso en el que se subsumió el argumento en el literal b) del artículo 31 de la LAM, pero se rechazó porque se consideró que la suspensión del plazo para laudar fue justificada. Ver, además, (i) Proceso No. 17100-2014-0059; y, (ii) Proceso No. 17100-2014-0077.

92. Supra [§ 4]. 


\subsection{Regulación del arbitraje internacional}

El Reglamento aborda al arbitraje internacional diferenciando los casos en los que Ecuador es sede del arbitraje y cuando la sede en el extranjero. Esta aproximación dual permite clarificar la aplicación de los artículos 41 y 42 de la LAM. Veamos.

En primer lugar, el artículo 2 del Reglamento dice que para los arbitrajes internacionales cuya sede sea Ecuador (i) le son aplicables los criterios objetivos y subjetivos del artículo 41 solamente93; y, (ii) se aclara que si bien el vehículo de inversión puede estar constituido en Ecuador, esto no determinará su domicilio, sino aquel del inversionista que lo controla el vehículo; es decir que si el domicilio del inversionista es distinto a Ecuador, el arbitraje será internacional.

En segundo lugar, el artículo 3 del Reglamento regula el arbitraje internacional con sede en el extranjero en el sector público. Como ya se mencionó, este es uno de los dos supuestos en los que es necesaria la autorización del Procurador General del Estado artículo 42 de la LAM-. Además, se delimita la función de dicha autorización en el sentido que esta deberá realizarse únicamente en cuanto al cumplimiento de requisitos previstos en legislación de la sede escogida, más no su conveniencia. Este artículo es de suma importancia ya que se deja claro que no existe una prohibición de la sede conforme el artículo 422 de la Constitución, como ciertos exponentes de un sector han alegado.

\subsection{Extensión del convenio arbitral}

Desde hace varios años atrás, ya se advertía la falta de regulación de la LAM respecto al fenómeno de incorporación de partes no signatarias a un proceso arbitral por haber manifestado

93. Ley de Arbitraje y Mediación, No. 3: "Un arbitraje podrá ser internacional cuando las partes así lo hubieren pactado, siempre y cuando se cumplan cualquiera de los siguientes requisitos: a) Que las partes al momento de la celebración del convenio arbitral, tengan sus domicilios en estados diferentes; b) Cuando el lugar de cumplimiento de una parte sustancial de las obligaciones o el lugar en el cual el objeto del litigio tenga una relación más estrecha, esté situado fuera del estado en que, por lo menos una de las partes, tiene su domicilio; o, c) Cuando el objeto del litigio se refiera a una operación de comercio internacional que sea susceptible de transacción y que no afecte o lesione los intereses nacionales o de la colectividad". 
su consentimiento de otras maneras y por ende, actuar como verdaderas partes ${ }^{94}$. El fundamento de esta noción es, primero, que "parte no es específicamente toda persona que concurre a la celebración del contrato sino solamente aquellas que configuran el 'centro de intereses del negocio'"95; y, segundo, que en virtud del principio de buena fe, se debe (o no) extender los efectos del convenio arbitral analizadas las circunstancias concretas del caso.

En su artículo 6 el Reglamento regula de manera expresa el fenómeno de partes no signatarias, estableciendo que los efectos del convenio arbitral alcanzan:

1. A aquellos cuyo consentimiento de someterse a arbitraje, según la buena fe, se determina por su participación activa y de manera determinante en la negociación, celebración, ejecución o terminación del contrato que comprende el convenio arbitral o al que el convenio esté relacionado.

2. A quienes pretendan derivar derechos o beneficios del contrato, según sus términos, tales como sucesores, cesionarios, entre otros.

3. A los organismos de las administraciones originadores de las actuaciones administrativas.

Consideramos que estas disposiciones modernizan el arbitraje en Ecuador, pues nos acercamos más a prácticas mundialmente aceptadas. Creemos pertinente aclarar que bajo ningún concepto la extensión de efectos a partes no suscriptoras del convenio arbitral, no se ve alterado el principio de relatividad de los contratos, ni se ve mermada la seguridad jurídica, ya que "el carácter voluntario del arbitraje sigue intacto" ${ }^{\prime \prime 6}$.

94. En términos generales se habla de las teorías de: (i) grupo de sociedades; (ii) incorporación por referencia; (iii) asunción de obligaciones; (iv) relación de agencia; v) levantamiento del velo societario o teoría del alter ego; (vi) doctrina de los actos propios; vii) cesión de derechos y obligaciones y de posición contractual; (viii) estipulación a favor de un tercero. Ver, H. GARCíA LARRIVA, "Partes no signatarias del convenio arbitral: entre la realidad económica y la ficción jurídica", Revista Ecuatoriana de Arbitraje, No. 3, 2011.

95. F. Messineo, Manual de Derecho Civil y Comercial, Buenos Aires: Ediciones Jurídicas Europa-América, 1954, citado en A.Orellana Ubidia, "El área gris entre la relatividad de los contratos y la inclusión de terceros no signatarios en el arbitraje", USFQ Law Review, No. 2, 2014, p. 30.

96. A. Orellana Ubidia, N. 95, p. 35. 



\section{estamos con}

\section{nuestros clientes}

en todas las fases del conflicto.

\section{somos especialistas}

en disputas cuya resolución requiere de un manejo minucioso y estratégico. 
